\title{
Apigenin oxidovanadium(IV) cation interactions. Synthesis, spectral, bovine serum albumin binding, antioxidant and anticancer studies
}

\author{
Juan J. Martínez Medina ${ }^{a}$, Luciana G. Nasob,*, Ana L. Pérez ${ }^{c}$, Alberto Rizzic, \\ Nora B. Okulik ${ }^{\mathrm{a}}$, Evelina G. Ferrer ${ }^{\mathrm{b}}$, Patricia A.M. Williams ${ }^{\mathrm{b}, *}$ \\ a Universidad Nacional del Chaco Austral, Comandante Fernández 755, CP: 3700, Presidencia Roque Sáenz Peña, Chaco, Argentina \\ ${ }^{\mathrm{b}}$ CEQUINOR, CONICET/UNLP, Facultad de Ciencias Exactas, Universidad Nacional de La Plata, Bv. $120 N^{\circ}$ 1465, 1900 La Plata, Argentina \\ ${ }^{\mathrm{c}}$ Departamento de Física, Facultad de Bioquímica y Ciencias Biológicas, Universidad Nacional del Litoral, Ciudad Universitaria-Paraje El Pozo, 3000 Santa Fe, \\ Argentina
}

\section{A R T I C L E I N F O}

\section{Article history:}

Received 22 March 2017

Received in revised form 19 April 2017

Accepted 3 May 2017

Available online 7 May 2017

\section{Keywords:}

Apigenin

Oxidovanadim(IV)

Cancer

Oxidative stress

Bovine serum albumin

\begin{abstract}
A B S T R A C T
Continuing and expanding our previous work on flavonoid oxidovanadium(IV) (VO) metal complexes as possible anti-cancer agents, the VOapigenin compound was synthesized and characterized. An "acetylacetone-like" coordination through the $\mathrm{C}=\mathrm{O}$ and $\mathrm{O}-$ moieties of the ligand to the metal center with one apigenin ligand per metal ion was assumed using different spectroscopies and elemental analysis as well as thermal measurements. The vibrational experimental spectrum of VOapigenin was supported by theoretical calculations. According to the structure of the flavonoid it exerted mild antioxidant properties that were enhanced by metal coordination. The compounds showed moderate anticancer activity on lung A549 and cervix HeLa cancer cell lines, displaying an incubation time dependent behavior. Cellular increase of reactive oxygen species (ROS) and glutathione depletion have been measured upon incubation with the compounds. These cell killing activities were reverted when natural antioxidants were incubated with the compounds and the addition of the antioxidant agent $\mathrm{N}$ acetylcysteine generated depletion of the cellular ROS levels. Therefore, a stress oxidative mechanism of action has been assumed. Moreover, the compounds showed no toxicity against Artemia salina and were not mutagenic. Both apigenin and the complex could be transported and stored by bovine serum albumin with similar binding constants and mechanisms than other VOflavonoid complexes.
\end{abstract}

(c) 2017 Elsevier B.V. All rights reserved.

\section{Introduction}

According to a study of the International Agency of Research for Cancer, it is expected that the mortality due to cancer may double in the next 50 years, rising to 10 million by the year 2020 [1]. Cervical cancer represents the second leading cause of death in

Abbreviations: AAPH, 2,2-azobis (2- amidinopropane) dihydrochloride; Apigenin (api), 5,7-dihydroxy-2-(4-hydroxyphenyl)-4H-chromen-4-one; BSA, Bovine serum albumin; DMEM, Dulbecco's Modified Eagle's medium; DPPH; 1,1-diphenyl2-picrylhydrazyl; FBS, fetal bovine serum; H2DCFDA, 2',7'-dichlorodihydrofluorescein diacetate; GSH, glutamylcysteinylglycine reduced glutathione; GSSG, oxidized glutathione; $\mathrm{LC}_{50}$, median lethal concentration; MI, mutagenic index; MTT, 3-(4,5-dimethylthiazol-2-yl)-2,5diphenyltetrazolium bromide; NAC, $\mathrm{N}$-acetyl-L-cysteine; NBT, nitroblue tetrazolium; PBS, phosphate-buffered saline; PMS, phenazine methosulfate; ROS, reactive oxygen species; VO(api), [VO(apigenin) $\left.\left(\mathrm{H}_{2} \mathrm{O}\right)_{2}\right] \mathrm{Cl}$.

Corresponding authors.

E-mail addresses: naso@quimica.unlp.edu.ar (L.G. Naso), williams@quimica.unlp.edu.ar (P.A.M. Williams). women worldwide and, in general, is strongly associated with the infection of human papiloma viruses (HPVs) [2,3], while lung cancer is the leading cause of cancer-related mortality worldwide and non-small cell lung cancer (NSCLC) accounts for higher than $80 \%$ of all lung cancers [4]. Researchers are being interested in natural compounds for enhancing cancer prevention and treatment. Plant-based diet contains substantial quantities of molecules that have chemopreventive potential to reduce the risk from several forms of human cancers. Flavonoids are phenolic compounds widely distributed in plants, which display a variety of biological activities, such as antioxidant, free radical scavengers, prevention of coronary heart disease and hepatoprotective, antiinflammatory, and anticancer activities [5].

Apigenin, 5,7-Dihydroxy-2-(4-hydroxyphenyl)-4H-chromen-4one (Fig. 1), is a flavonoid belonging to the flavones structural class, present in abundance in fruits and vegetables such as oranges, grapefruit, celery, parsley, onions, chamomile and wheat sprouts. It has been reported that apigenin is a potent inhibitor of cell growth and inducer of apoptosis in various human cancer cells [6] and 


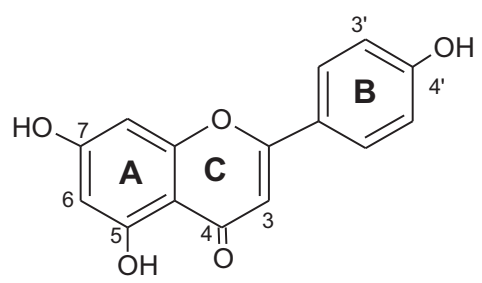

Fig. 1. Schematic representation of apigenin.

several pathways of the inhibition of proliferation have been proposed $[7,8]$. Besides, there exist evidence that apigenin induced apoptosis by generation of reactive oxygen species (ROS) on different cancer cell lines [9-13].

The most rational approach to cancer chemoprevention is to design and test new agents that act on specific molecular and cellular targets. Since many flavonoids are natural chelators and flavonoid metal complexes have showed significantly higher cytotoxic activity than those of the parent flavonoids, we have been preparing several oxidovanadium(IV) ion (VO) complexes with flavonoids for over ten years and determined the improvement of their anticancer activities and their mechanisms of action [14]. The aim of this study is to prepare a new oxidovanadium(IV) based antitumor compound with apigenin (api) and investigate the biological behavior and a probable synergistic effect. Human lung A549 and human cervix cancer HeLa cell lines have been selected to study the possible anticancer effect of VOapi. The complex VOapi has been characterized by FTIR, EPR, UV-vis and diffuse reflectance spectroscopic studies both in solid state and in solution. DFT computational studies have been performed to optimize the structure of the complex and to study the vibrational spectrum. According to the structure of apigenin the flavonoid behaves as a mild antioxidant agent, but this property has been improved by coordination to the metal center. However, both compounds are able to produce reactive oxygen species (ROS) in both cell lines. The depletion of the tripeptide $\gamma$-glutamylcysteinylglycine, glutathione levels in its reduced form (GSH), associated with the increase of ROS in cells is an indication that the mechanism of action of the compounds occurs through oxidative stress. Toxicological studies demonstrated that the complex and the parent drugs did not show either toxicity (Artemia salina test) or mutagenicity (Ames test) and it has also been determined that the compounds could be stored and transported by bovine serum albumin (BSA).

\section{Experimental}

\subsection{Materials and methods}

Apigenin (Xi'an App-Chem Bio(Tech) Co., Ltd) and oxidovanadium(IV) chloride (50\% aqueous solution, Carlo Erba) were used as supplied. Corning or Falcon provided tissue culture materials. Dulbecco's modified Eagle's medium (DMEM) was purchased from Gibco (Gaithersburg, MD, USA), Tryple ${ }^{\mathrm{TM}}$ from Invitrogen (Argentina SRL) and fetal bovine serum (FBS) from Internegocios, Argentina. All other chemicals used were of analytical grade. Elemental analysis for carbon and hydrogen was performed using a Carlo Erba EA1108 analyzer. Vanadium content was determined by the tungstophosphovanadic method [15]. Chloride contents were measured using an ion-selective electrode (Cole-Parmer 27.50212). A Shimadzu system (model TG-50), working in an oxygen flow of $50 \mathrm{~mL} \mathrm{~min}{ }^{-1}$ and at a heating rate of $10^{\circ} \mathrm{C} \cdot \mathrm{min}^{-1}$ has been used for the thermogravimetric analysis. Sample quantities ranged between 10 and $20 \mathrm{mg}$. UV-vis and diffuse reflectance spectra ( $\mathrm{MgO}$ as a standard) were recorded with a Shimadzu 2600/2700 spectrophotometer. Infrared spectra were measured with a Bruker IFS 66 FTIR spectrophotometer from 4000 to $400 \mathrm{~cm}^{-1}$ using the $\mathrm{KBr}$ pellet technique. X-band CW-EPR spectra of powdered samples were obtained at room temperature on a Bruker EMXPlus spectrometer, equipped with a rectangular cavity with $100 \mathrm{kHz}$ field modulation. X band EPR spectra of frozen DMSO solutions were recorded at $120 \mathrm{~K}$, after addition of 5\% DMSO to ensure good glass formation. EPR spectra were simulated with the EasySpin toolbox based on MATLAB [16]. Fluorescence spectra were obtained using a Shimadzu (RF6000) luminescence spectrometer equipped with a pulsed xenon lamp. The molar conductance of the complex was measured on a Conductivity TDS Probe -850084 , Sper Scientific Direct, using $10^{-3}$ M DMSO solutions.

\subsection{Synthesis of $[\mathrm{VO}$ (apigenin $\left.)\left(\mathrm{H}_{2} \mathrm{O}\right)_{2}\right] \mathrm{Cl}$, VOapi}

Apigenin $(0.5 \mathrm{mmol})$ was dissolved in absolute ethanol under heating and stirring. After cooling, $\mathrm{VOCl}_{2}$ (50\% aqueous solution, $0.25 \mathrm{mmol}$ ) was added to the ligand solution under stirring, under nitrogen atmosphere. The $\mathrm{pH}$ of the solution was adjusted to 5 by addition of $1 \mathrm{M} \mathrm{NaOH}$ solution and the solvent was removed up to $2 \mathrm{~mL}$ under vacuum. The suspension was filtered and the green powder, characterized as [VO(apigenin) $\left.\left(\mathrm{H}_{2} \mathrm{O}\right)_{2}\right] \mathrm{Cl}$ (VOapi), was washed three times with absolute ethanol and dried in an oven at $60{ }^{\circ} \mathrm{C}$. Anal. calcd. For $\mathrm{C}_{15} \mathrm{H}_{13} \mathrm{O}_{8} \mathrm{VCl}$ : $\mathrm{C} 44.1, \mathrm{H} 3.2, \mathrm{~V} 12.5, \mathrm{Cl}$ 8.7. Found: C 44.2, $\mathrm{H} 3.2, \mathrm{~V} 12.4, \mathrm{Cl} 8.8 \%$. Thermogravimetric analysis (oxygen atmosphere, $50 \mathrm{~mL} / \mathrm{min}$ ): The water loss finishes at relatively high temperatures, $\left(187^{\circ} \mathrm{C}\right)$ and the total release of water involves two water molecules $\left(\Delta \mathrm{w}_{\text {calc }}=8.3 \%, \Delta \omega_{\text {exp }}=8.4 \%\right.$ ). According to the temperature of dehydration it has been assumed that the two water molecules belong to the coordination sphere of the oxidovanadium(IV) cation. After dehydration, the compound degraded in a series of two consecutive TG steps observed up to $600^{\circ} \mathrm{C}$. Weight constancy is attained $700^{\circ} \mathrm{C}$ and the weight of the remaining solid residue, collected at $700{ }^{\circ} \mathrm{C}$ was of $22.4 \%$, in good agreement with the expected value of $22.3 \%$. The presence of $\mathrm{V}_{2} \mathrm{O}_{5}$ in the residue was confirmed by FTIR spectroscopy. Diffuse reflectance: 268 , sh $\mathrm{nm}, 360 \mathrm{~nm}, 395 \mathrm{~nm}, 453 \mathrm{~nm},>800 \mathrm{~nm}$. The molar conductance of the complex measured in DMSO, $\Lambda_{\mathrm{m}}=29$ $\left(\Omega^{-1} \cdot \mathrm{cm}^{2} . \mathrm{mol}^{-1}\right)$, suggested a 1:1 electrolyte [17].

\subsection{Computational methodology for assignment of vibrational modes}

As suitable single crystals for structural determinations could not be obtained, the geometrical parameters and the vibrational determinations and assignments of $\mathrm{VO}(\mathrm{api})$ were studied by computational methodologies. Theoretical calculations were performed using tools from density functional theory (DFT) [1820] as implemented in the GAUSSIAN 09 program package [21]. The structural and electronic properties of the ligand apigenin were further studied by using DFT calculations [22-24] and the optimization procedures were carried out using the Beck threeparameters hybrid exchange-correlation functional, known as B3LYP [25] and employing the 6-311G basis set [26] reached by adding polarization and diffuse functions for all atoms. This further optimized geometry was employed to build the oxidovanadium (IV) complex VOapi. The complex was first optimized at the same level of theory that the ligand and then reoptimized employing different functionals and basis set [27].

Molecular structure of the ligand and the complex VOapi were optimized in gas phase. Vibrational calculations at the same level of theory were performed to determine the consistency of the minimum in the potential energy surface and to assign the theoretical vibrational spectra. The IR frequencies were analyzed 
by means of Potential Energy Distribution (PED\%) calculation using Vibrational Energy Distribution Analysis (VEDA 4) program [28].

\subsection{Spectrophotometric titrations and stability studies}

To establish the stoichiometry of the complex in solution the molar ratio method was applied. A solution of apigenin (EtOH, $4 \times 10^{-5} \mathrm{M}$ ) was prepared and its electronic spectrum recorded. The absorption spectra of different ethanolic solutions of $4 \times 10^{-5} \mathrm{M}$ apigenin and $\mathrm{VOCl}_{2}$ in ligand-to-metal molar ratios from 10 to 0.5 ( $\mathrm{pH} 5.0, \mathrm{NaOH}$ and $\mathrm{N}_{2}$ atmosphere) were measured. Plots of the absorbance at $298 \mathrm{~nm} v$ s the ligand-to-metal ratios allowed the stoichiometric determination. Stability studies have been performed measuring the variation of the VOapi electronic absorption spectra (DMSO, $\mathrm{N}_{2}$ ) vs. time.

\subsection{Antioxidant properties}

The superoxide dismutase (SOD) activity was examined indirectly using the nitroblue tetrazolium (NBT) assay. The indirect determination of the activity of apigenin and the VOapi was assayed by their ability to inhibit the reduction of NBT by the superoxide anion generated by the phenazine methosulfate (PMS) and reduced nicotinamide adenine dinucleotide (NADH) system. As this reaction proceeded, the formazan color developed and a change from yellow to blue was observed which was associated with an increase of the intensity of the band at $560 \mathrm{~nm}$ in the absorption spectrum. The system contained $0.5 \mathrm{~mL}$ of sample, $0.5 \mathrm{~mL}$ of $1.40 \mathrm{mM} \mathrm{NADH}$ and $0.5 \mathrm{~mL}$ of $300 \mu \mathrm{M} \mathrm{NBT}$, in $0.1 \mathrm{M}$ $\mathrm{KH}_{2} \mathrm{PO}_{4}-\mathrm{NaOH}$ buffer ( $\mathrm{pH} 7.5$ ). After incubation at $25^{\circ} \mathrm{C}$ for $15 \mathrm{~min}$, the reaction was started by adding $0.5 \mathrm{~mL}$ of $120 \mu \mathrm{M}$ PMS. Then, the reaction mixture was incubated for $5 \mathrm{~min}$. Each experiment was performed in triplicate and at least three independent experiments were performed in each case. The amount of compound that gave a $50 \%$ inhibition $\left(\mathrm{IC}_{50}\right)$ was obtained by plotting the percentage of inhibition versus the negative log of the concentration of the tested solution.

The capacity of apigenin and the VOapi to scavenge hydroxyl radicals (generated by the ascorbate-iron- $\mathrm{H}_{2} \mathrm{O}_{2}$ system) has been measured. Briefly, the reaction mixture contained $3.75 \mathrm{mM} \mathrm{2-}$ deoxyribose, $2.0 \mathrm{mM} \mathrm{H}_{2} \mathrm{O}_{2}, 100 \mu \mathrm{M} \mathrm{FeCl}$, and $100 \mu \mathrm{M}$ EDTA without or with the tested compounds in $20 \mathrm{mM} \mathrm{KH}_{2} \mathrm{PO}_{4}-\mathrm{KOH}$ buffer, $\mathrm{pH}$ 7.4. The reaction was triggered by the addition of $100 \mu \mathrm{M}$ ascorbate and the mixture was incubated at $37^{\circ} \mathrm{C}$ for $30 \mathrm{~min}$. Solutions of $\mathrm{FeCl}_{3}$, ascorbate, and $\mathrm{H}_{2} \mathrm{O}_{2}$ were made up in deaerated water immediately before use. The extent of deoxyribose degradation by hydroxyl radical was measured with the thiobarbituric acid method [29].

The inhibition of peroxyl radical was measured by generation of the radicals by the thermal decomposition of 2,2-azobis (2amidinopropane) dihydrochloride (AAPH) [30]. AAPH was chosen due to its ability to generate free radicals at a steady rate for extended periods of time (half-life of $175 \mathrm{~h}$ ). The consumption of pyranine was followed spectrophotometrically by the decrease in absorbance at $454 \mathrm{~nm}$ with a thermostated cell at $37^{\circ} \mathrm{C}$. The reaction solutions contained $\mathrm{AAPH}(50 \mathrm{mM})$, pyranine $(50 \mu \mathrm{M})$ and several concentrations of the tested compounds. The delay of pyranine consumption (lag phase) was calculated as the time before the consumption of pyranine started (notable reductions in absorbance) [31].

The antiradical activity of apigenin and VOapi was also measured in terms of the capacity of the compounds to scavenge $\mathrm{DPPH}^{\bullet}$ (1,1-diphenyl-2-picrylhydrazyl) radicals. The measurements were performed in triplicate using a modified method of Yamaguchi et al. [32]. A methanolic solution of (DPPH $\left.{ }^{\bullet}\right)(4 \mathrm{~mL}$, $40 \mathrm{ppm}$ ) was added to $1 \mathrm{~mL}$ of the antioxidant solutions in $0.1 \mathrm{M}$ tris(hydroxymethyl)aminomethane- $\mathrm{HCl}$ buffer ( $\mathrm{pH} 7.1$ ) at $25^{\circ} \mathrm{C}$, giving a final concentration of $10 \mu \mathrm{M}$. After $60 \mathrm{~min}$ in the dark, the absorbance at $517 \mathrm{~nm}$ was measured and compared with the absorbance of the control prepared in a similar way without the addition of the antioxidants (this value was assigned arbitrarily as $100 \%)$.

\subsection{Biological assays}

\subsubsection{Cell culture}

Human lung cancer cell line A549 and human cervical cancer cell line HeLa were maintained at $37^{\circ} \mathrm{C}$ in a $5 \%$ carbon dioxide atmosphere using DMEM supplemented with $100 \mathrm{U} / \mathrm{mL}$ penicillin, $100 \mu \mathrm{g} / \mathrm{mL}$ streptomycin and $10 \%(\mathrm{v} / \mathrm{v}$ ) fetal bovine serum as the culture medium. When $70-80 \%$ confluence was reached, cells were subcultured using TrypLE ${ }^{\mathrm{TM}}$ from Gibco (Gaithersburg, MD, USA) and free phosphate buffered saline (PBS) $\left(11 \mathrm{mM} \mathrm{KH}_{2} \mathrm{PO}_{4}, 26 \mathrm{mM}\right.$ $\mathrm{Na}_{2} \mathrm{HPO}_{4}, 115 \mathrm{mM} \mathrm{NaCl}, \mathrm{pH}$ 7.4). For the experiments, cells were grown in multi-well plates. When cells reached $70 \%$ confluence, the monolayers were washed twice with DMEM and then incubated with the different compounds.

\subsubsection{MTT (3-(4,5-dimethylthiazol-2-yl)-2,5diphenyltetrazolium bromide) assay}

A549 and HeLa cells were seeded at a density of $1 \times 10^{5}$ per well in 48 well plates, grown overnight and treated with either vehicle, apigenin, VOapi or oxidovanadium(IV) cation at different concentrations in FBS free medium. Dimethyl sulfoxide (DMSO) has been used as the dissolution vehicle to yield a maximum final concentration of $0.5 \%$ in the treated well (Sigma-Aldrich, St. Louis, MO). After 24,48 or $72 \mathrm{~h}$ of incubation at $37^{\circ} \mathrm{C}, 100 \mu \mathrm{g}$ per well MTT (Sigma-Aldrich, St. Louis, MO) was added and incubated for $2 \mathrm{~h}$. The formazan products generated by cellular reduction of MTT were dissolved in isopropyl alcohol/ $\mathrm{HCl}$ and the optical density was measured at $560 \mathrm{~nm}$. All experiments were performed in triplicate. Data were presented as percentage of cell viability (\%) of the treated group with respect to the untreated cells (control) in which the viability is assumed to be $100 \%$. To evaluate the cell viability in the presence of natural antioxidants, the cells were incubated with different concentrations of the apigenin and VOapi plus a mixture of vitamins $C$ and $\mathrm{E}$ ( $50 \mu \mathrm{M}$ each) during $24 \mathrm{~h}$. Then, the MTT assay was performed [14].

\subsubsection{ROS measurements}

Intracellular reactive oxygen species (ROS) generation in A549 and HeLa cell lines was measured by oxidation of $2^{\prime}, 7^{\prime}$ dichlorodihydrofluorescein diacetate $\left(\mathrm{H}_{2} \mathrm{DCFDA}\right)$ to $2^{\prime}, 7^{\prime}$-dichlorofluorescein (DCF). Briefly, 24-well plates were seeded with $5 \times 10^{4}$ cells per well and allowed to adhere overnight. Then, different concentrations of apigenin, VOapi and oxidovanadium(IV) cation were added for $24 \mathrm{~h}$. Following the compounds treatment, media was removed and cells were loaded with $10 \mu \mathrm{M} \mathrm{H}_{2}$ DCFDA diluted in clear media for $30 \mathrm{~min}$ at $37^{\circ} \mathrm{C}$. Media was then separated and the cell monolayers rinsed with PBS and lysated into $1 \mathrm{~mL} 0.1 \%$ Triton-X100. The cell extracts were then analyzed for the oxidized product DCF by fluorescence spectroscopy (excitation wavelength, $485 \mathrm{~nm}$; emission wavelength, $535 \mathrm{~nm}$ ) [33]. Using the same assay as described above, ROS generation in cells was measured in the presence of NAC ( $N$-acetylcysteine). Cells were pretreated with $5 \mathrm{mM}$ of NAC for $30 \mathrm{~min}$, followed by treatment with apigenin and VOapi at different concentrations for additional $24 \mathrm{~h}$.

\subsubsection{Fluorometric determination of cellular GSH and GSSG levels}

Glutathione (GSH) and Oxidized glutathione (GSSG) levels were determined in A549 and HeLa cell lines in culture. Confluent cell monolayers from 24 well dishes were incubated with different 
concentrations of apigenin, VOapi and oxidovanadium(IV) cation at $37^{\circ} \mathrm{C}$ for $24 \mathrm{~h}$. Then, the monolayers were washed with PBS and harvested by incubating them with $300 \mu \mathrm{L}$ Triton $0.1 \%$ for $30 \mathrm{~min}$. For GSH determinations, $100 \mu \mathrm{L}$ aliquots were mixed with $1.8 \mathrm{~mL}$ of ice cold phosphate buffer $\left(\mathrm{Na}_{2} \mathrm{HPO}_{4} 0.1 \mathrm{M}\right.$-EDTA $\left.0.005 \mathrm{M}, \mathrm{pH} 8\right)$ and $100 \mu \mathrm{L}$ o-phthaldialdehyde (OPT) (0.1\% in methanol) as it was described by Hissin and Hilf [34]. For the determination of GSSG, $100 \mu \mathrm{L}$ aliquots were mixed with $1.8 \mathrm{~mL} \mathrm{NaOH} 0.1 \mathrm{M}$ and OPT but previously and to avoid GSH oxidation, the cellular extracts for GSSG determination were incubated with $0.04 \mathrm{M}$ of N-ethylmaleimide (NEM). The fluorescence at an emission wavelength of $420 \mathrm{~nm}$ was determined after excitation at $350 \mathrm{~nm}$. Standard curves with different concentrations of GSH were processed in parallel. The protein content in each cellular extract was quantified using the Bradford assay [35]. The ratio GSH/GSSG, which is a better marker for the cellular redox status, was calculated as\% control for all the experimental conditions.

\subsubsection{Cell morphology}

To evaluate the morphology of the cells, they were grown in six well per plates and incubated overnight with fresh serum-free DMEM plus 0 (basal), 10 and $100 \mu \mathrm{M}$ solutions of the complex. The monolayers were subsequently washed twice with PBS, fixed with methanol and stained with 1:10 dilution of Giemsa for $10 \mathrm{~min}$. Next, they were washed with water and the morphological changes were examined by light microscopy.

\subsection{Toxicological assays}

\subsubsection{Artemia salina test}

For the determination of the acute toxicity of the metal, the ligand apigenin, $\mathrm{VOCl}_{2}$ and the VOapi complex in brine shrimp, eggs of $A$. salina were incubated in a hatching chamber with artificial seawater at $20-30^{\circ} \mathrm{C}$ (One liter of seawater contains: $\mathrm{NaCl}, 23 \mathrm{~g} ; \mathrm{MgCl}_{2} \cdot 6 \mathrm{H}_{2} \mathrm{O}, 11 \mathrm{~g} ; \mathrm{Na}_{2} \mathrm{SO}_{4}, 4 \mathrm{~g} ; \mathrm{CaCl}_{2} \cdot 2 \mathrm{H}_{2} \mathrm{O}, 1.3 \mathrm{~g} ; \mathrm{KCl}$, $0.7 \mathrm{~g}$ ). The $\mathrm{pH}$ was adjusted to 9.0 using $\mathrm{Na}_{2} \mathrm{CO}_{3}$ to avoid risk of death to the Artemia larvae by the decrease of $\mathrm{pH}$ during incubation. [36] After $24 \mathrm{~h}$, the larvae (nauplii) were extracted and counted using a micropipette. For the oxidovanadium(IV) cation, the ligand apigenin and the VOapi complex, six concentrations (in triplicate) were tested in order to determine the doseresponse relationship and negative (distilled water) and a positive $\left(\mathrm{K}_{2} \mathrm{Cr}_{2} \mathrm{O}_{7}\right)$ controls were used. Concentrations tested were 300,150 , $75,37.5,18.8$, and $9.4 \mu \mathrm{g} \cdot \mathrm{mL}^{-1}$. The selected concentrations were in the order of those used for the anticancer determinations. The wells containing the sample and 10 larvae of brine shrimp, including the control groups, were filled to a total volume of $100 \mu \mathrm{L}$ with artificial seawater. After $24 \mathrm{~h}$, live larvae were counted and the median lethal concentration $\left(\mathrm{LC}_{50}\right)$ values were estimated.

\subsubsection{Ames test}

The mutagenic potential of novel drugs needs to be investigated because some chemical agents which show mutagenicity can induce cancer. Mutagenicity of the compounds was evaluated by the Salmonella/microsome assay that is based on the plateincorporation method proposed by Maron and Ames [37], using Salmonella typhimurium TA98 and Salmonella typhimurium TA100. The test strains were obtained from frozen culture and were grown overnight for $12-14 \mathrm{~h}$ at $37^{\circ} \mathrm{C}$ in Mueller Hinton broth. The different concentrations of the metal, the ligand apigenin and the VOapi complex $(300,150,75,37.5$ and $18.8 \mu \mathrm{g} /$ plate $)$ were added to $2 \mathrm{~mL}$ of top agar mixed with $100 \mu \mathrm{L}$ of bacterial culture $\left(1-2 \times 10^{8}\right.$ cells $\mathrm{mL}^{-1}$ ) adding this mixture to a plate with minimal agar. These plates were incubated at $37^{\circ} \mathrm{C}$ for $48 \mathrm{~h}$ and the number of His+ revertant colonies was counted. All experiments were made in duplicate. The Mutagenic index (MI) was calculated as the average number of revertants per plate divided by the average number of revertants per plate from the negative control for each dose.

\subsection{Bovine serum albumin (BSA) interaction}

BSA was dissolved in Tris- $\mathrm{HCl}(0.1 \mathrm{M}, \mathrm{pH} 7.4)$ buffer to attain a final concentration of $6 \mu \mathrm{M}$. Solutions of apigenin and VOapi were added dropwise to the BSA solution and left to rest to ensure the formation of homogeneous solutions with concentrations ranging from 2 to $100 \mu \mathrm{M}$ with an incubation time of $1 \mathrm{~h}$. The fluorescence intensity was measured (excitation at $280 \mathrm{~nm}$ ) at 298, 303 and $310 \mathrm{~K}$. For each sample and concentration, three independent replicates were performed. Both excitation and emission slits were set at $10 \mathrm{~nm}$ throughout this study.

\section{Results and discussion}

\subsection{Solid characterization of the complex}

\subsubsection{Vibrational spectroscopy}

The vibrational FTIR spectral data of the solids apigenin, its sodium salt (Na-apigenin) and VOapi in $\mathrm{KBr}$ pellets is displayed in Table 1. The major changes in the infrared spectrum upon coordination are:

Table 1

Tentative assignments of the FTIR spectra of apigenin, its sodium salt Na-apigenin and VOapi (band postitions in $\mathrm{cm}^{-1}$ ).

\begin{tabular}{|c|c|c|c|}
\hline apigenin & Na-apigenin & VOapi & Assignments \\
\hline $3322 \mathrm{sh}, 3279 \mathrm{~m}$ & $3417 \mathrm{~m}$ & $3380 \mathrm{~m}$ & $v(\mathrm{O}-\mathrm{H}) \mathrm{H}$-bond \\
\hline $3092 \mathrm{~m}$ & $3058 \mathrm{~m}$ & $3087 \mathrm{~m}$ & $v(\mathrm{C}-\mathrm{H})$ \\
\hline $2922 \mathrm{~m}, 2831 \mathrm{~m}$ & $2974 \mathrm{~m}, 2925 \mathrm{~m}, 2855 \mathrm{~m}$ & $2954 \mathrm{~m}, 2893 \mathrm{~m}, 2822 \mathrm{~m}$ & $v(\mathrm{C}-\mathrm{H})$ \\
\hline $2762 \mathrm{~m}, 2695 \mathrm{~m}, 2616 \mathrm{~s}$ & & $2766 \mathrm{~m}, 2693 \mathrm{~m}, 2630 \mathrm{~m}$ & H-bond \\
\hline 1657 vs & 1660 vs & 1638 vs & $v(C=0)$ \\
\hline 1612 vs & 1602 vs & 1596 vs & $v(\mathrm{C}=\mathrm{O})+v(\mathrm{C} 2=\mathrm{C} 3)$, ring A quinoid stretching vibration \\
\hline $1584 \mathrm{~s}$ & $1582 \mathrm{sh}$ & - & $\delta(\mathrm{OH})+$ ring stretching vibration \\
\hline $1556 \mathrm{~s}$ & 1556 vs & 1529 vs & $v(\mathrm{C}=\mathrm{C})$, Ring $\mathrm{C}$ \\
\hline 1498 vs & $1499 \mathrm{~m}$ & 1492 vs & $\delta(\mathrm{CH})_{\text {inplane, }} v(\mathrm{C}=\mathrm{C})$ \\
\hline $1447 \mathrm{~s}$ & $1439 \mathrm{~m}$ & $1452 \mathrm{~m}$ & $\delta(\mathrm{CH})_{\text {inplane, }} v(\mathrm{C}=\mathrm{C})$ \\
\hline 1355 vs & 1372 s, $1340 \mathrm{sh}$ & $1353 \mathrm{~s}$ & $v(\mathrm{C}-\mathrm{OH})+v(\mathrm{CC})$ \\
\hline 1243 vs & $1241 \mathrm{~s}$ & $1246 \mathrm{~s}$ & $v(\mathrm{C}-\mathrm{O}-\mathrm{C}), v(\mathrm{C}-\mathrm{OH})$ \\
\hline $1223 \mathrm{~s}$ & - & - & $v(\mathrm{CH})_{\text {inplane, }}, \delta(\mathrm{OH})$ \\
\hline 1178 vs, 1159 sh & 1169 vs & 1171 vs & $\delta(\mathrm{C}-\mathrm{OH})_{\text {inplane }}$ \\
\hline $1114 \mathrm{~m}$ & $1121 \mathrm{~m}$ & $1104 \mathrm{~m}$ & $v(\mathrm{C}-\mathrm{OH}), \delta(\mathrm{C}-\mathrm{H}$ aromatic ring $)$ \\
\hline $1029 \mathrm{~m}$ & $1023 \mathrm{w}$ & $1040 \mathrm{~m}$ & $\delta(\mathrm{CH})_{\text {inplane }}$ \\
\hline- & - & $977 \mathrm{~m}$ & $v(\mathrm{~V}=\mathrm{O})$ \\
\hline
\end{tabular}

s, strong; vs, very strong; w, weak; m, medium; sh, shoulder. $v$ : stretching vibration; $\delta$ : bending vibration. 
- The $\mathrm{C}=\mathrm{O}$ stretching band $\left(1657 \mathrm{~cm}^{-1}\right.$ in apigenin and $1660 \mathrm{~cm}^{-1}$ in Na-apigenin) is shifted to lower energies $\left(1638 \mathrm{~cm}^{-1}\right.$ in the complex) owing to the increase in length of the $\mathrm{C}=\mathrm{O}$ bond coordinated to the oxidovanadium(IV) cation.

- The deprotonation and coordination to $\mathrm{O}(5)$ is indicated by the presence of the strong band at $1584 \mathrm{~cm}^{-1}$ in apigenin that disappears upon deprotonation and or complexation.

- The modifications of ring A were detected by the displacements of the bands $1612 \mathrm{~cm}^{-1}$ in apigenin and $1602 \mathrm{~cm}^{-1}$ in $\mathrm{Na}-$ apigenin at $1596 \mathrm{~cm}^{-1}$ in the complex. The modifications of ring $C$ were detected by the displacements of the bands $1556 \mathrm{~cm}^{-1}$ in apigenin and Na-apigenin at $1529 \mathrm{~cm}^{-1}$ in the complex.

- The shift of the band assigned to $\delta(\mathrm{CH})_{\text {inplane }}$ from $1029 \mathrm{~cm}^{-1}$ in apigenin and $1023 \mathrm{~cm}^{-1}$ in Na-apigenin to $1040 \mathrm{~cm}^{-1}$ in the complex indicate the alteration of the ring structure.

- The band at $1243 \mathrm{~cm}^{-1}$ associated with $v(\mathrm{C}-\mathrm{O}-\mathrm{C})$ changed slightly upon complexation, indicating that the ring oxygen of the ligand did not form metal-oxygen bonds with the metal ion.

- The band corresponding to the vibrations of ring B at $1498 \mathrm{~cm}^{-1}$ was not affected by the interaction of apigenin with the metal center.

- The position of the $\mathrm{V}=\mathrm{O}$ stretching band at $977 \mathrm{~cm}^{-1}$ is typical for a coordination sphere of $\left(\mathrm{CO}, \mathrm{O}^{-}\right)$or "acetylacetone-like" with flavonoids. This conclusion is supported by the measurements of the EPR spectra (see below).

These results suggest that the coordination of the oxidovanadium(IV) ion with the apigenin ligand most probably took place via carbonyl oxygen and 5-OH group after deprotonation to form the metal-oxygen bonds in the complex.

\subsubsection{EPR measurements}

Fig. 2 shows the powder EPR spectrum obtained at room temperature. A very similar spectrum was obtained at low temperature (not shown). The EPR spectrum of VOapi microcrystalline powder gave a unique EPR line, which does not show the typical eight lines hyperfine splitting pattern of ${ }^{51} \mathrm{~V}$ nucleus ( $\mathrm{I}=7$ / 2 ). This fact indicates the presence of magnetic interactions between paramagnetic oxidovanadium(IV) ions in the solid complex, which collapse the hyperfine interaction. A similar behavior has been found for VOnaringenin and VOquercetin complexes [38,39].

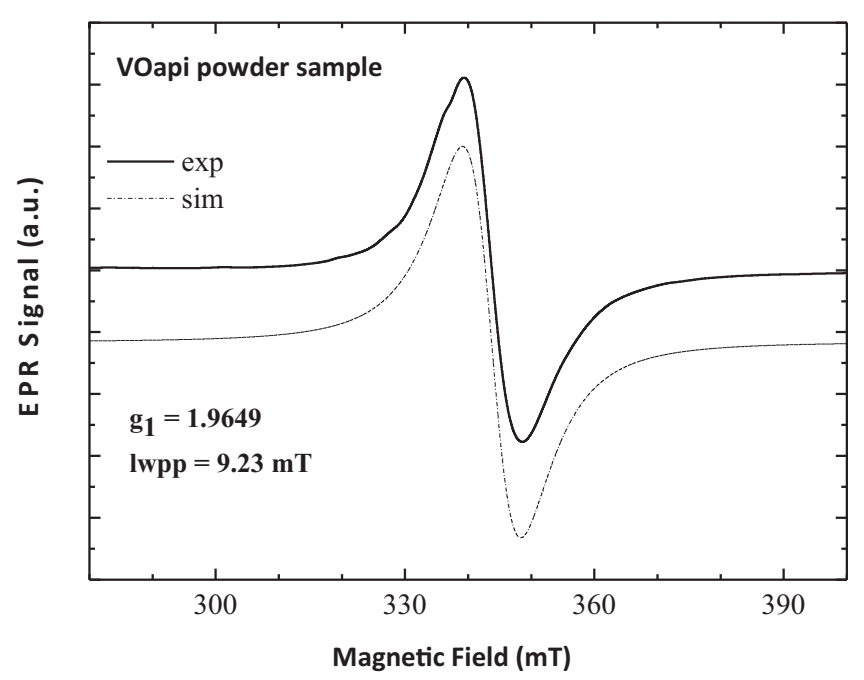

Fig. 2. Powder EPR spectrum of VOapi obtained at $293 \mathrm{~K}$ (solid) together with simulation (dash dot). Microwave frequency $9.4565 \mathrm{GHz}$ g-factor and linewidth peak-to-peak (lwpp) obtained by simulation are indicated.

\subsubsection{DFT calculations}

The optimized structures of the ligand and the complex Vapi are depicted in Figs. 3 and 4, respectively. Computational studies apigenin at the B3LYP level of theory with different basis sets were previously reported in the literature $[22,23,40]$. Then, the ligand apigenin was optimized at the level of theory B3LYP/6-311++G** without any constrains. For the complex VOapi, the optimization was carried out employing different functionals (B3LYP, B3P86, M06L, PBE1PBE, MPW1PW91 and B97D) and basis sets $\left(6-31 \mathrm{G}^{* *}\right.$ and $\left.6-311++G^{* *}\right)$. While the triple zeta valence basis set $6-311+$ $+G^{* *}$, developed by Pople and coworkers [26], results the best choice, our results indicate that calculation employing the functional B97D appears to be the most advantageous one, taking into account the better correlation with the experimental FTIR spectrum. Minenkov et al. [40] have investigated the performance of 8 popular density functionals in reproducing 18 molecular structures derived from single-crystal X-ray diffraction experiments on ruthenium-based olefin metathesis catalyst precursors. These authors find that all the methods accounting for dispersion (B97D, wB97XD, M06, and M06L) give rise to more compact structures, removing the systematic overestimation of internuclear distances, and suggest a ranking of this functionals (B97D $<$ M06 $\approx$ wB97XD $<$ M06L). However, they conclude that taking into account the well-known oscillation problems of the Minnesota functionals, B97D is a tempting and computationally less demanding choice. The experimental data (conductimetric, thermogravimetric and elemental analysis) allowed the confirmation that only one ligand coordinated to the metal center. From the spectroscopic determinations the coordination mode of the ligand to the metal center is suggested to occur through $\mathrm{C}=\mathrm{O}$ and $\mathrm{O}-$ moieties with "acetylacetone-like" coordination, similar to the coordination oxidovanadium(IV) complexes of chrysin and morin as predicted by Sanna et al. for acidic $\mathrm{pH}$ values [41]. The coordination sphere is completed by two water molecules (determined by thermogravimetric measurements). The optimized structure of VOapi indicates that this complex is a pentacoordinated complex with distorted square pyramidal geometry. Representative bond lengths and angles around the vanadium atom are depicted in Table 2. Taking into account the coordination sphere around the vanadium center, it can be seen that the calculated $\mathrm{V}=\mathrm{O}$ bond length $(1.576 \AA$ ) resulted with an intermediate value between those of bisacetylacetonate oxidovanadium(IV) $(1.56 \AA)[42]$ and the hydrated $\left[\mathrm{VO}\left(\mathrm{H}_{2} \mathrm{O}\right)_{5}\right]^{2+}$ ion $(1.582 \AA)[43]$. Besides, the $\mathrm{C}=\mathrm{O}$ bond in apigenin of $1.253 \AA$ resulted enlarged upon coordination $1.309 \AA$, as expected.

The experimental and the theoretical FTIR spectra of the complex VOapi, calculated at the same level of theory employed in the optimization procedure $\left(\mathrm{B} 97 \mathrm{D} / 6-311++\mathrm{G}^{* *}\right)$, are shown in

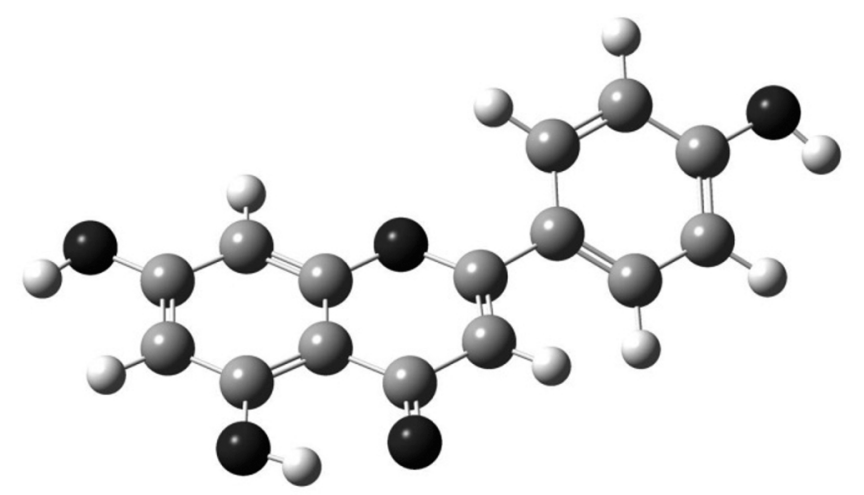

Fig. 3. Optimized geometry of apigenin at the level of theory B3LYP/6-311++G** The gray ball represents $\mathrm{C}$ atom, the black ball represents $\mathrm{O}$ atom and the white ball represents $\mathrm{H}$ atom. 


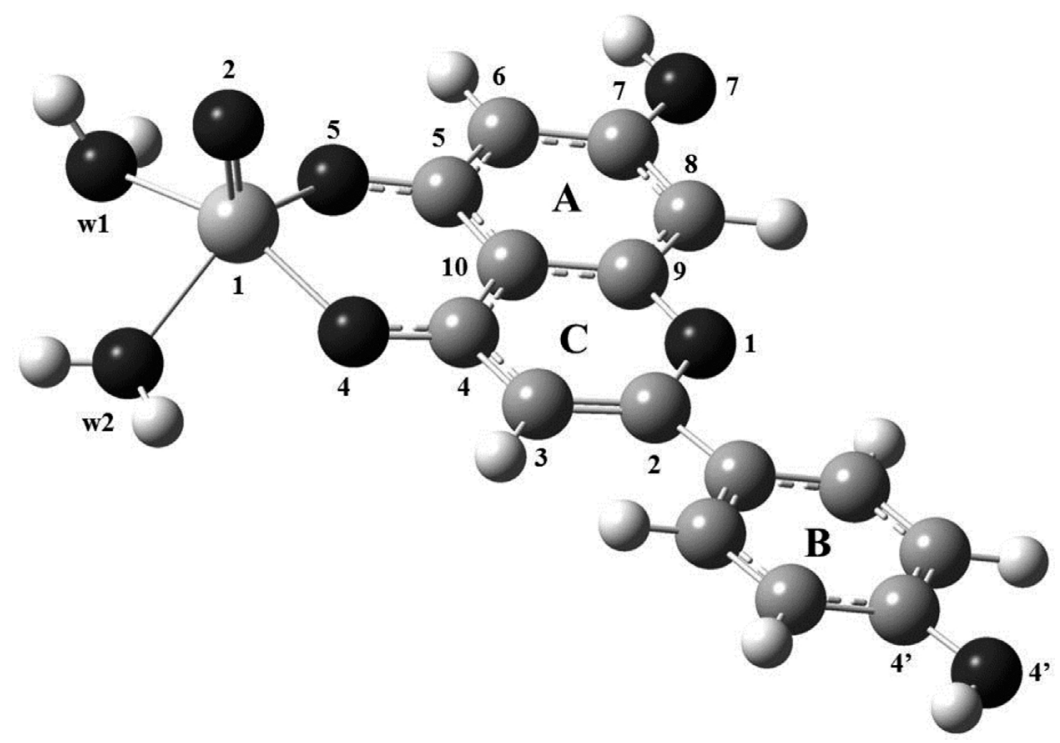

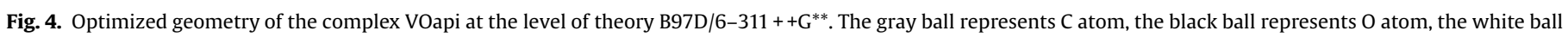
represents $\mathrm{H}$ atom and the light gray ball represents $\mathrm{V}$ atom.

\section{Table 2}

Selected bond lengths $(\AA)$ and angles $\left(^{\circ}\right)$ around Vanadium in the VOapi complex calculated at B97D/6-311 $++\mathrm{G}^{* *}$ level of theory.

\begin{tabular}{llll}
\hline Bond Lenghts $^{\mathrm{a}}$ & VOapi & Bond Angles $^{\mathrm{a}}$ & VOapi $^{\mathrm{a}}$ \\
\hline $\mathrm{V}(1)-\mathrm{O}(2)$ & 1.576 & $\mathrm{O}(2)-\mathrm{V}(1)-\mathrm{O}(\mathrm{w} 1)$ & 99.09 \\
$\mathrm{~V}(1)-\mathrm{O}(\mathrm{w} 1)$ & 2.180 & $\mathrm{O}(2)-\mathrm{V}(1)-\mathrm{O}(\mathrm{w} 2)$ & 111.99 \\
$\mathrm{~V}(1)-\mathrm{O}(\mathrm{w} 2)$ & 2.119 & $\mathrm{O}(2)-\mathrm{V}(1)-\mathrm{O}(4)$ & 107.40 \\
$\mathrm{~V}(1)-\mathrm{O}(4)$ & 1.947 & $\mathrm{O}(2)-\mathrm{V}(1)-\mathrm{O}(5)$ & 112.76 \\
$\mathrm{~V}(1)-\mathrm{O}(5)$ & 1.893 & & \\
$\mathrm{C}(5)-\mathrm{O}(5)$ & 1.338 & & \\
$\mathrm{C}(4)-\mathrm{O}(4)$ & 1.309 & & \\
\hline
\end{tabular}

a For the denomination of the atoms see Fig. 4.
Fig. 5. Experimental and calculated data show reasonable agreement, even without the use of scaling factors. However, an exhaustive vibrational study indicates that the calculated FTIR spectrum is slightly different from the experimental one. For example, the band at $977 \mathrm{~cm}^{-1}$ in the experimental spectrum was assigned to the $\mathrm{V}=\mathrm{O}$ stretching, whereas in the simulation this vibrational mode appears at $1045 \mathrm{~cm}^{-1}$. This difference could be explained by the fact that the IR spectrum was measured in the solid state in which the structure is subjected to intra and intermolecular interactions such us hydrogen bonding and van der Waals interactions, whereas the calculations for the isolated molecule have been performed in gas phase. In this context, the

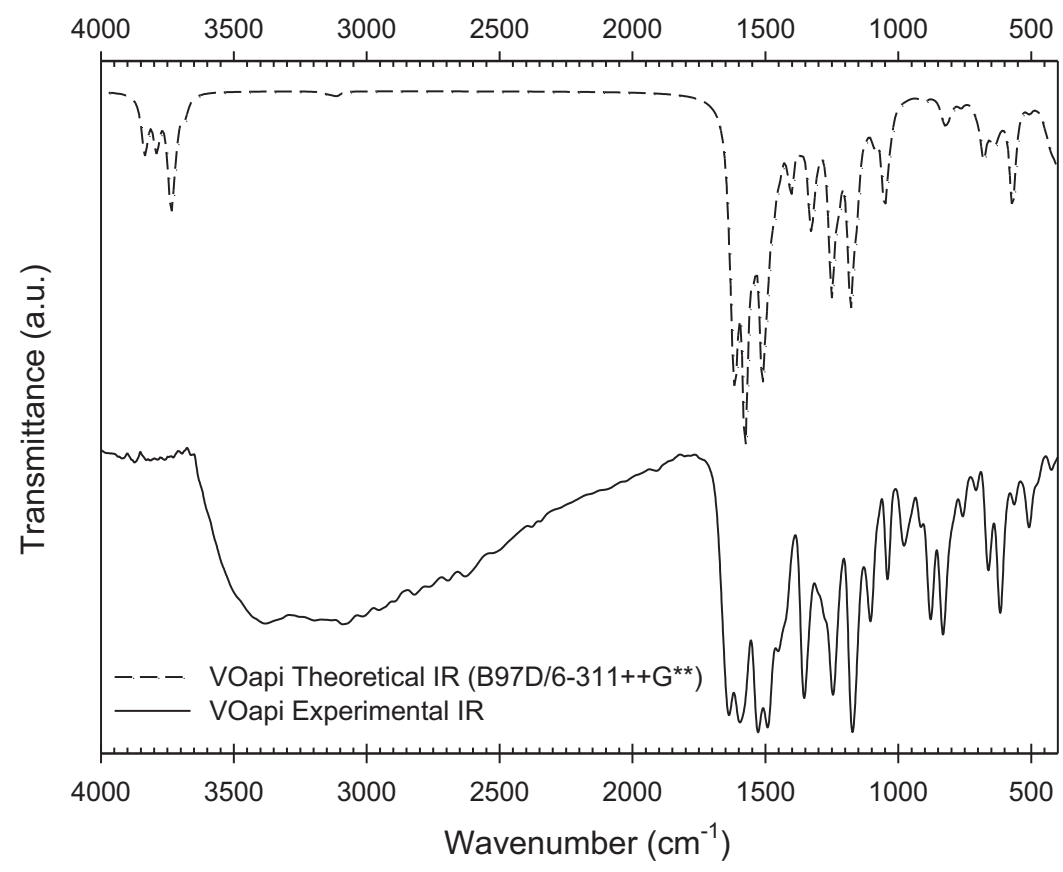

Fig. 5. Experimental IR spectrum (solid) and theoretical FTIR spectrum (dashed) of the VOapi complex. 
Potential Energy Distribution (PED) analysis is an indispensable tool for a serious analysis of the vibrational spectra. The analysis of vibrational results was carried out employing VEDA 4 program in order to identify the most important components in each vibrational mode with a description using internal coordinates. The results of PED analysis are displayed in Table S1 and the contribution percentages of each coupled mode for the same wavenumber are indicated in parentheses. For comparative purposes, Table S1 includes previously reported data of the vibrational spectrum of apigenin calculated at B3LYP/6-31G(d,p) level of theory (scaled by 0.9608 ) [24].

\subsection{Solution studies}

\subsubsection{Electronic spectra}

The UV-vis spectrum of the ligand and complex were recorded in DMSO/EtOH (1/100).

Two acid-base dissociation steps were reported for apigenin: $\mathrm{pKa}_{1}=6.61 \pm 0.07$ and $\mathrm{pKa}_{2}=9.31 \pm 0.07$ [44]. Apigenin at $\mathrm{pH}$ values up to 8 exhibits two major absorption bands in the UVvis region, at $340 \mathrm{~nm}$ (band I) representing B-ring absorption (cinnamoyl system), and the absorption in $269 \mathrm{~nm}$ (band II) associated with the A ring portion (benzoyl system).They are related to the $\pi \rightarrow \pi^{*}$ and $\mathrm{n} \rightarrow \pi^{*}$ transitions. At $\mathrm{pH}$ values higher than 9, the absorption spectra is shifted to the long-wavelength region, $345 \mathrm{~nm}$ to $390 \mathrm{~nm}$ ( $\mathrm{pH} 9$ to 11) (band I) as shown in Fig. S1. It is observed that deprotonation causes a rather large shift probably because of the extension of the conjugated system established by the deprotonated $\mathrm{ArO}^{-}$groups.

The UV-vis spectra of a 1:1 mixture of apigenin:oxidovanadium (IV) cation (Fig. S2) showed a similar spectral pattern than the ligand in the $250-500 \mathrm{~nm}$ region. By comparing both spectral variations it can be shown that both deprotonation and/or chelation induced those spectral changes which are qualitatively parallel in the UV-vis spectral region. Working with 100-fold concentrated solutions the oxidovanadium(IV) $d-d$ transitions can be observed (Fig. S3). At pH values of 2 to 3 the typical spectra of VO (IV) cation in DMSO ([VO(DMSO $\left.\left.)_{5}\right]^{2+}\right)$ is displayed. Spectral changes at higher $\mathrm{pH}$ values (from $650 \mathrm{~nm}$ to $570 \mathrm{~nm}$ ) are indicative of the coordination of the metal with the flavonoid from $\mathrm{pH}$ values higher than 4 . Then, a $\mathrm{pH}$ value of 5 has been selected for the synthesis of the complex. The spectrophotometric titration has been performed following the spectral variation of an ethanolic $4 \times 10^{-5} \mathrm{M}$ solution of apigenin at $\mathrm{pH} 5$ with the

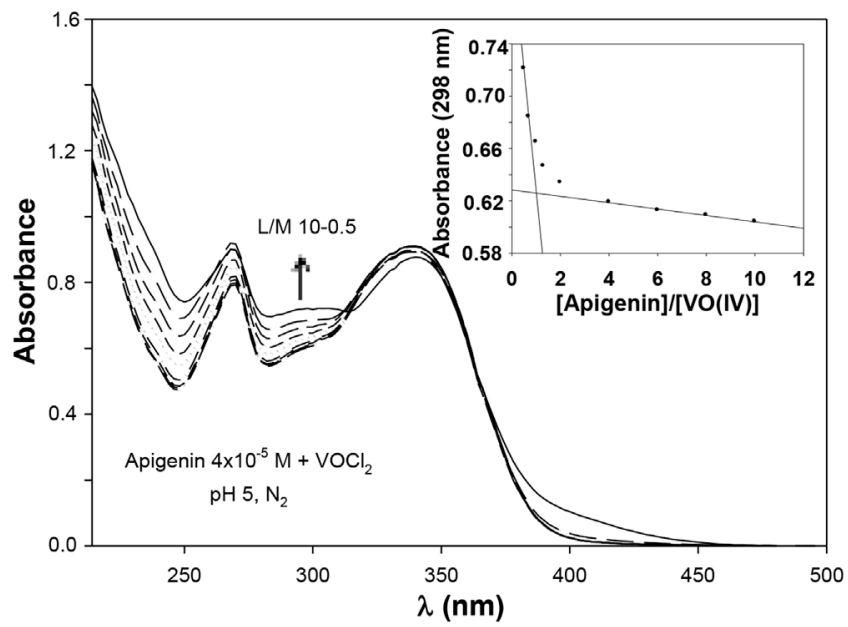

Fig. 6. UV-vis spectra of apigenin $\left(4 \times 10^{-5} \mathrm{M}\right)$ with the addition of $\mathrm{VOCl}_{2}$ in ligandto-metal ratios from 10.0 to 0.5 ( $\mathrm{pH} \mathrm{5),} \mathrm{nitrogen} \mathrm{atmosphere.} \mathrm{Inset:} \mathrm{spectrophoto-}$ metric determination of VOapi complex stoichiometry at $298 \mathrm{~nm}$. successive addition of $\mathrm{VOCl}_{2}$ at different ratios, at $298 \mathrm{~nm}$. A ligand-to-metal ratio 1-1 has been obtained in agreement with the stoichiometry determined for the solid complex (see Fig. 6).

The complex remained stable in a DMSO solution (no appreciable changes were observed in the UV-vis spectra) at least during $1 \mathrm{~h}$ (data not shown). Then it can be stated that the complex did not decompose during the manipulation of the solution for the biological studies.

\subsubsection{EPR spectrum in solution}

Fig. 7 shows the EPR spectrum obtained in a DMSO frozen solution at $120 \mathrm{~K}$. The EPR signal shows the typical eight-line pattern spectrum for the oxidovanadium(IV) cation systems. The solution experimental spectrum can be well simulated assuming g-and A-matrices with rhombic symmetry. This signal indicated the formation of single mononuclear species after the dissolution process. The spectral simulation predicted the formation of an oxidovanadium(IV) chromophore with spin Hamiltonian parameters $g_{z}=1.9439, g_{x}=1.9767$ and $g_{y}=1.9717$ and hyperfine coupling constants of $A_{z}=166.8 \times 10^{-4} \mathrm{~cm}^{-1}, A_{x}=52.3 \times 10^{-4} \mathrm{~cm}^{-1}$, and $A_{y}=61.2 \times 10^{-4} \mathrm{~cm}^{-1}$.

Using the additivity rule [45] a calculated value of $A_{z}=169.9$ $\times 10^{-4} \mathrm{~cm}^{-1} \quad\left(\mathrm{C}=\mathrm{O} \quad 44.7 \times 10^{-4} \mathrm{~cm}^{-1}, \quad \mathrm{ArO}^{-} 38.6 \times 10^{-4} \mathrm{~cm}^{-1}\right.$, $\mathrm{O}_{\text {DMSO }}=43.3 \mathrm{~cm}^{-1}$ [46]) has been obtained assuming that the two coordination water molecules have been replaced by two solvent molecules in the equatorial plane (DMSO). This value is in good agreement with the experimental $A_{z}$ value.

\subsubsection{Antioxidant determinations}

The antioxidant properties have been evaluated by means on the capacity of the compounds to scavenge reactive oxygen species (ROS) in vitro. In addition, the capacity of the reduction of the concentration of the $\mathrm{DPPH}^{\bullet}$ radical has been evaluated for comparative purposes (Table 3 ).

Apigenin did not display SOD activity, as has previously been reported [47] and the coordination to oxidovanadium(IV) cation did not improve this activity. The flavonoid showed no activity on the peroxyl radical scavenging (no phase lag of pyranine consumption detected at $200 \mu \mathrm{M}$ ) while VOapi showed low activity (phase lag of pyranine consumption of $1.62 \mathrm{~min}$, at $100 \mu \mathrm{M})$. Apigenin and VOapi at a $100 \mu \mathrm{M}$ concentration displayed

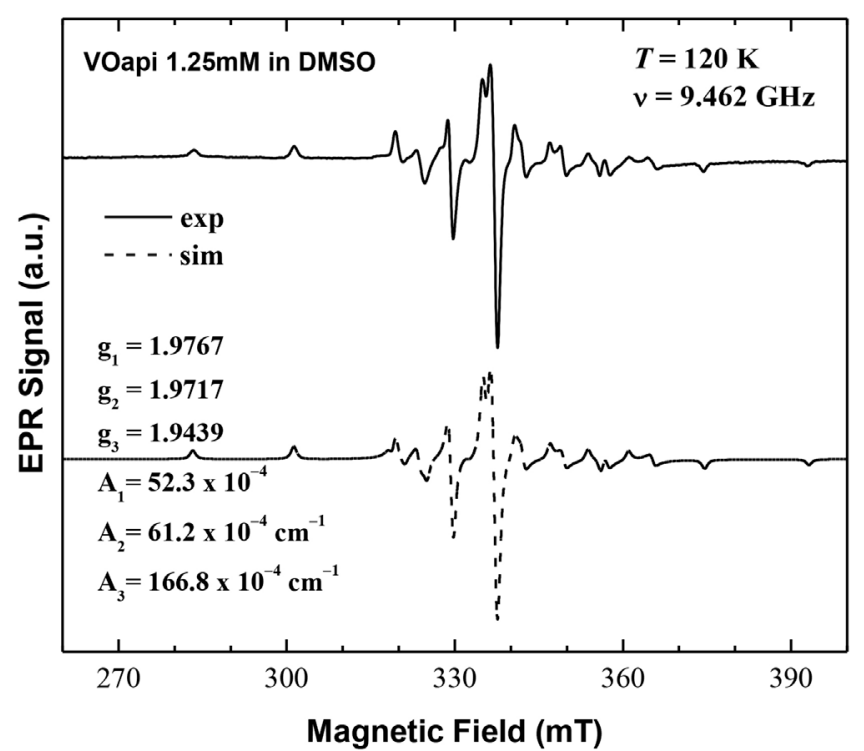

Fig. 7. Frozen solution EPR spectrum of VOapi (solid) together with simulation (dashed). Temperature, microwave frequency, and EPR parameters obtained by simulation are indicated. 
Table 3

Antioxidant activities of apigenin, VOapi and the oxidovanadium(IV) cation. ${ }^{\text {a }}$ from ref [51].

\begin{tabular}{|c|c|c|c|c|}
\hline Compounds & $\mathrm{O}_{2}{ }^{-}-\left(\mathrm{IC}_{50}, \mu \mathrm{M}\right)$ & $\mathrm{DPPH}^{\bullet}\left(\mathrm{IC}_{50}, \mu \mathrm{M}\right)$ & $\mathrm{OH}^{\bullet}\left(\mathrm{IC}_{50}, \mu \mathrm{M}\right)$ & $\mathrm{ROO}^{\bullet}$ (lag phase, $\mathrm{min}$ ) \\
\hline apigenin & $>100$ & $>100$ & 10 & $<1,100 \mu \mathrm{M}$ \\
\hline luteolin ${ }^{\mathrm{a}}$ & $>100$ & 68 & 100 & $3.19,10 \mu \mathrm{M}$ \\
\hline VOapi & $>100$ & $>100$ & 52 & $1.62,100 \mu \mathrm{M}$ \\
\hline VOlut $^{\mathrm{a}}$ & $>100$ & $>100$ & 17 & $2.15,10 \mu \mathrm{M}$ \\
\hline $\mathrm{V}(\mathrm{IV}) \mathrm{O}^{2+}$ & 15 & $>100$ & $>100$ & $\begin{array}{l}<1,100 \mu \mathrm{M} \\
1.2,10 \mu \mathrm{M}\end{array}$ \\
\hline Native SOD & 0.21 & & & \\
\hline
\end{tabular}

antioxidant activity against $\mathrm{OH}^{\bullet}$ radicals scavenging $64 \%$ and 53\% of the radicals, respectively. A similar effect for apigenin has previously been shown [48]. Besides, a weak radical scavenging potential against $\mathrm{DPPH}^{\bullet}$ radicals has been reported for apigenin $[49,50]$. Table 3 shows that apigenin and VOapi at a $100 \mu \mathrm{M}$ concentration were able to scavenge $3 \%$ and $16 \%$ of the $\mathrm{DPPH}^{\bullet}$ radicals, respectively.

The low antioxidant activity of apigenin is related to its chemical structure. The presence of only one hydroxyl group in ring $\mathrm{B}$ and the lack of the $\mathrm{OH}$ group in 3- position directly impact on its low radical scavenging behavior. Moreover, the absence of $3^{\prime}-$ hydroxyl group is especially essential for the antioxidant potency of flavonoids, because the o-dihydroxy arrangement in ring B have better electron-donating properties to form ketones after scavenging radicals. In this context, it can be seen that apigenin is structurally related to luteolin with the same substituents in A and $C$ rings, but differs in the hydroxyl $(\mathrm{OH})$ substitutions in ring $\mathrm{C}$. Luteolin possesses $3^{\prime}$ - and $4^{\prime}$ - cis diol groups in ring B. According to the relation of the flavonoid structure with its activity, a higher antioxidant activity has been measured for $\mathrm{DPPH}^{\bullet}$ and $\mathrm{ROO}^{\bullet}$ radicals for luteolin. However, the oxidovanadium(IV) complex of apigenin improved $\mathrm{DPPH}^{\bullet}$ and peroxyl scavenging activities but the complex with luteolin did not exhibit higher scavenger power [51]. This behavior could be explained by the mode of coordination of the ligands. In VOluteolin metal coordination involves 3'-OH and $4^{\prime}-\mathrm{OH}$ groups of ring $\mathrm{B}$, precluding the involvement of these groups in the antioxidant action of the complex. On the contrary, the apigenin coordination involves $\left(\mathrm{C}=\mathrm{O}\right.$ and $\left.\mathrm{O}^{-}\right)$groups of rings $\mathrm{A}$ and $C$ in the chelation to the oxidovanadium(IV) cation that might enhance electron delocalization of the odd electron of ring $C$ by $\pi$ conjugation when it acts as a radical scavenger, generating a more stable radical.

\subsection{Biological assays}

\subsubsection{Cell viability}

It has previously been shown that apigenin slightly affected the viability of A549 cells at $24 \mathrm{~h}$ incubation [12,52,53] and that the oxidovanadium(IV) cation induced no cytotoxicity to A549 human lung cancer cells at the tested concentrations (16\% inhibition at $100 \mu \mathrm{M}$ ) [38]. From Fig. 8A it can be seen that the viability of A549 cells at $24 \mathrm{~h}$ was also slightly affected when the cells were treated with VOapi with $\mathrm{IC}_{50}$ values $>100 \mu \mathrm{M}$.

On the other hand, the effect of the compounds on the HeLa cell line viability at $24 \mathrm{~h}$ incubation was more pronounced. Oxidovanadium(IV) cation inhibited $40 \%$ of cell viability at $100 \mu \mathrm{M}$ $\left(\mathrm{IC}_{50}>100 \mu \mathrm{M}\right)$, as it was previously reported [54] and apigenin induced cytotoxicity on HeLa cells with approximately 60\% reduction of cell viability at concentration of $100 \mu \mathrm{M}\left(\mathrm{IC}_{50}=85.4\right.$ $\mu \mathrm{M})$, in agreement with previous results $[53,55,56]$. The complex VOapi showed lower cytotoxicity than the ligand at low concen-

Table 4

$\mathrm{IC}_{50}$ values for apigenin and VOapi at 24,48 and $72 \mathrm{~h}$ on A549 and HeLa cell lines.

\begin{tabular}{|c|c|c|c|c|c|c|}
\hline & \multicolumn{2}{|c|}{$\mathrm{IC}_{50}(\mu \mathrm{M}), 24 \mathrm{~h}$} & \multicolumn{2}{|c|}{$\mathrm{IC}_{50}(\mu \mathrm{M}), 48 \mathrm{~h}$} & \multicolumn{2}{|c|}{$\mathrm{IC}_{50}(\mu \mathrm{M}), 72 \mathrm{~h}$} \\
\hline & A549 & HeLa & A549 & HeLa & A549 & HeLa \\
\hline Apigenin & $>100$ & $85.4 \pm 1.7$ & $24.8 \pm 2.9$ & $20.3 \pm 3.2$ & $9.1 \pm 1.8$ & $7.6 \pm 2.1$ \\
\hline VOapi & $>100$ & $88.1 \pm 1.4$ & $17.7 \pm 3.1$ & $15.5 \pm 1.6$ & $2.2 \pm 0.9$ & $9.7 \pm 1.9$ \\
\hline
\end{tabular}

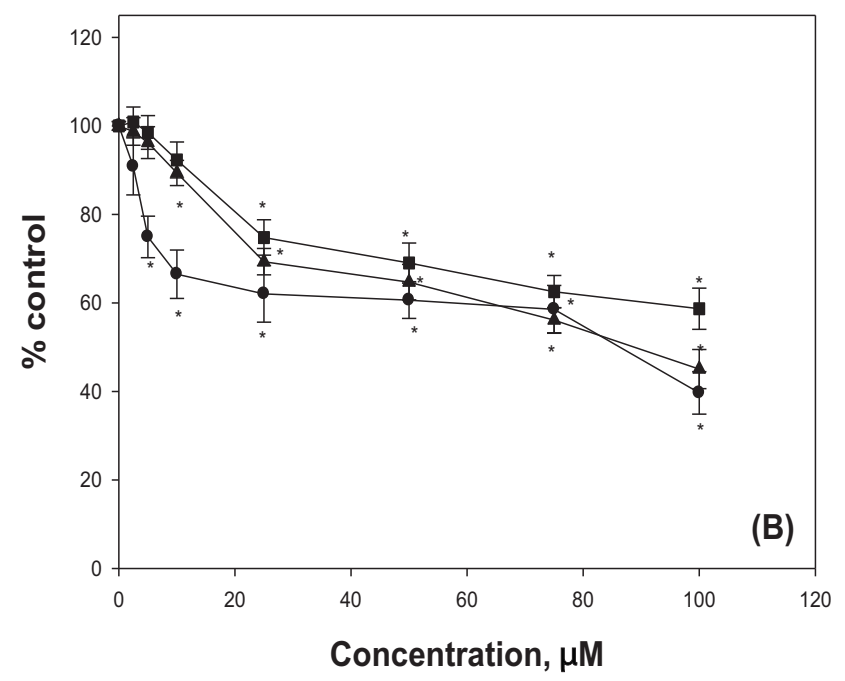

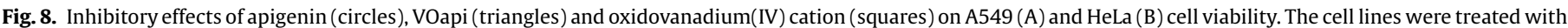

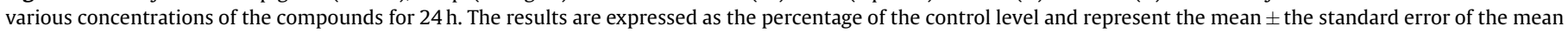
(SEM) from three separate experiments. * significant values in comparison with the control level $(\mathrm{P}<0.05)$. 
trations $(<50 \mu \mathrm{M})$ and at higher concentrations the behavior was similar to that of the ligand (Fig. 8B). Apigenin and VOapi concentrations ranging from 2.5 to $100 \mu \mathrm{M}$; at 48 and $72 \mathrm{~h}$ incubation showed a time-dependent cell viability decrease (see Table 4) on both cell lines. The effects of the free ligand and its complex with oxidovanadium(IV) cation at all the measured incubation times were similar on the HeLa cell line and only a low improvement of the anticancer effect of the flavonoid upon coordination has been shown for the lung cancer cell line at $72 \mathrm{~h}$ incubation.

It is worth mentioning that there are some discrepancies in the literature data for the cell viability of A549 and HeLa cell lines at 48 and $72 \mathrm{~h}$ with the reported results being quite different from each othe $[9,27,53-59]$.

\subsubsection{Mechanisms of action}

Normal cells contain fewer amounts of both ROS and antioxidants in relation to cancer cells and ROS homeostasis suffer small changes upon loss of either ROS or antioxidants, maintaining cells viable and functional. On the contrary, cancer cells have higher levels of ROS and antioxidants, and then the increase of ROS generation and/or the inhibition of antioxidant produced oxidative cancer cell death, while the opposite effect, prevention of ROS generation or treatment with antioxidants will produce cytostasis and possibly senescence $[60,61]$. Therefore, the persistent pro-oxidative state characterizing cancer cells, as well as their multiple adaptation mechanisms to minimize the effects of oxidative damage can be used to develop new therapeutic strategies. To try to elucidate the mechanism by which apigenin, VOapi and oxidovanadium(IV) cation exert their cytotoxic effects, we examined the intracellular levels of ROS in compound-treated A549 and HeLa cells using the probe DCFH-DA. This probe is cellpermeable and is cleaved by non-specific esterases and is oxidized by the ROS produced in the cells to form DCF. Then, the intensity of DCF fluorescence is proportional to the amount of ROS production. It can be observed in Fig. 9 that apigenin and VOapi produced the same effects in both cell lines. In A549 cell line, both compounds produced a slight increment of ROS levels at concentrations higher than $80 \mu \mathrm{M}$. The oxidovanadium(IV) cation did not increase the cellular ROS levels [14].

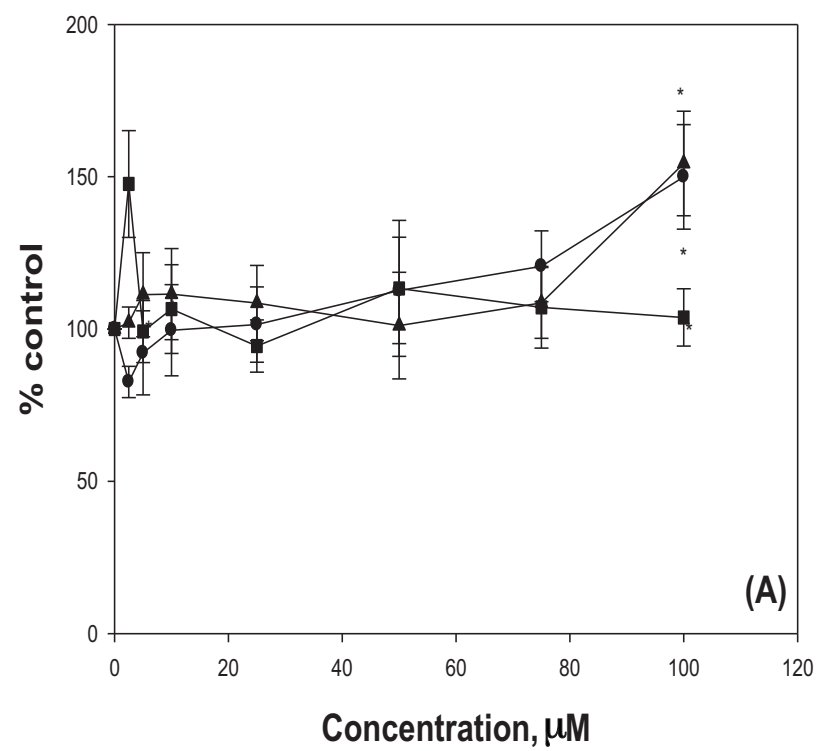

The anticancer activity of the structural related flavonoid luteolin (high peroxyl scavenger capacity) in the A549 cell line at $24 \mathrm{~h}$ incubation is higher than that of apigenin (better hydroxyl scavenger) but in both cases complexation did not improve the cytotoxic behavior and the cellular ROS generation of the ligand even though the in vitro antioxidant power changed upon oxidovanadium(IV) complexation because of the different coordination modes with each flavonoid. It is important to be mentioned that despite ROS production of both compounds on A549 cell line is similar for the ligands and the complexes, in the case of apigenin and VOapi, ROS and cytotoxic effects begin in parallel (at concentrations higher than $80 \mu \mathrm{M}$ at $24 \mathrm{~h}$ incubation). Therefore, stress oxidative mechanisms could be assumed for the cell-killing action in both cases.

On the other hand, the treatment with apigenin and VOapi in HeLa cells caused a significant enhance in ROS accumulation in mitochondria with a dose-dependent behavior (approximately $230 \%$ of the control level at $100 \mu \mathrm{M}$ ) as compared with untreated control cells. Oxidovanadium(IV) cation generated a lower increment of ROS levels $(150 \%$ at $100 \mu \mathrm{M})$. The oxidative stress increase induced by the compounds correlates quite well with the inhibition of cell viability in both cancer cell lines producing cancer-oxidative cell death.

Glutathione is the major nonenzymatic regulator of intracellular redox homeostasis, ubiquitously present in all cell types at millimolar concentration. It exists in two forms, reduced (GSH) and oxidized (GSSG) and participates in redox reactions by the reversible oxidation of its active thiol. Within cells, total GSH exists free and bound to proteins. Since the enzyme glutathione reductase, which reverts free glutathione from its oxidized form is constitutively active and inducible upon oxidative stress, free glutathione is present almost exclusively in its reduced form [62]. In mammalian cells under physiological conditions, the GSH redox couple is known to be present with steady-state concentrations of 1-10 mM. The overall ratio of GSH/GSSG in a cell is usually greater than 100:1, and the redox couple GSH/GSSG is used as indicator of changes in the redox environment and of oxidative stress in the cell. In various models of oxidative stress, this ratio has been demonstrated to decrease to values of 10:1 and even 1:1 [63]. As a marker of cellular toxicity, the concentration of GSH was measured

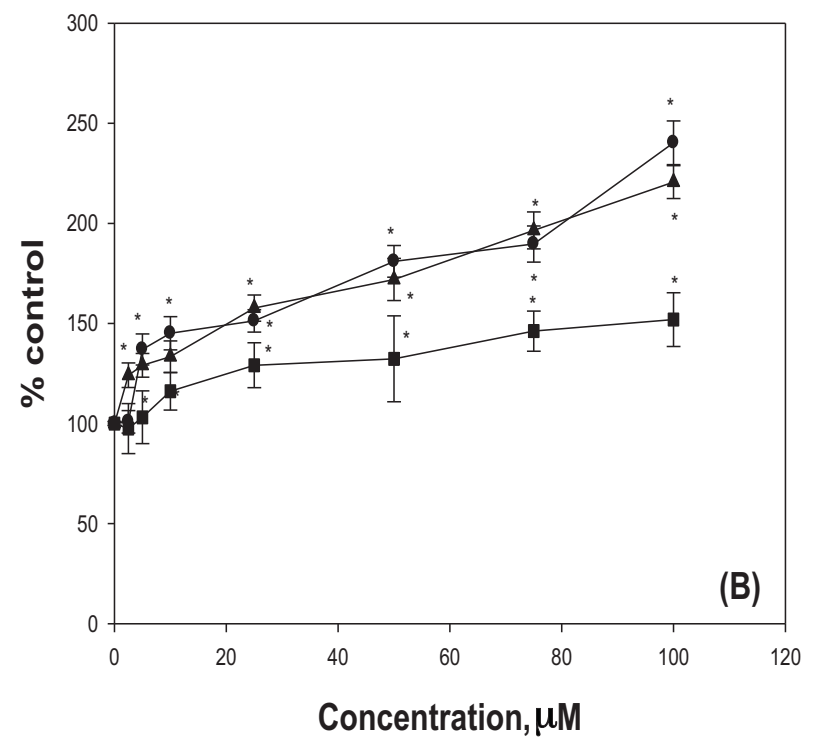

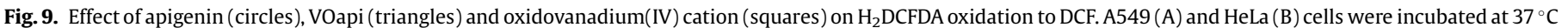

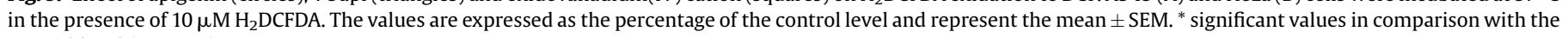
control level $(\mathrm{P}<0.05)$. 

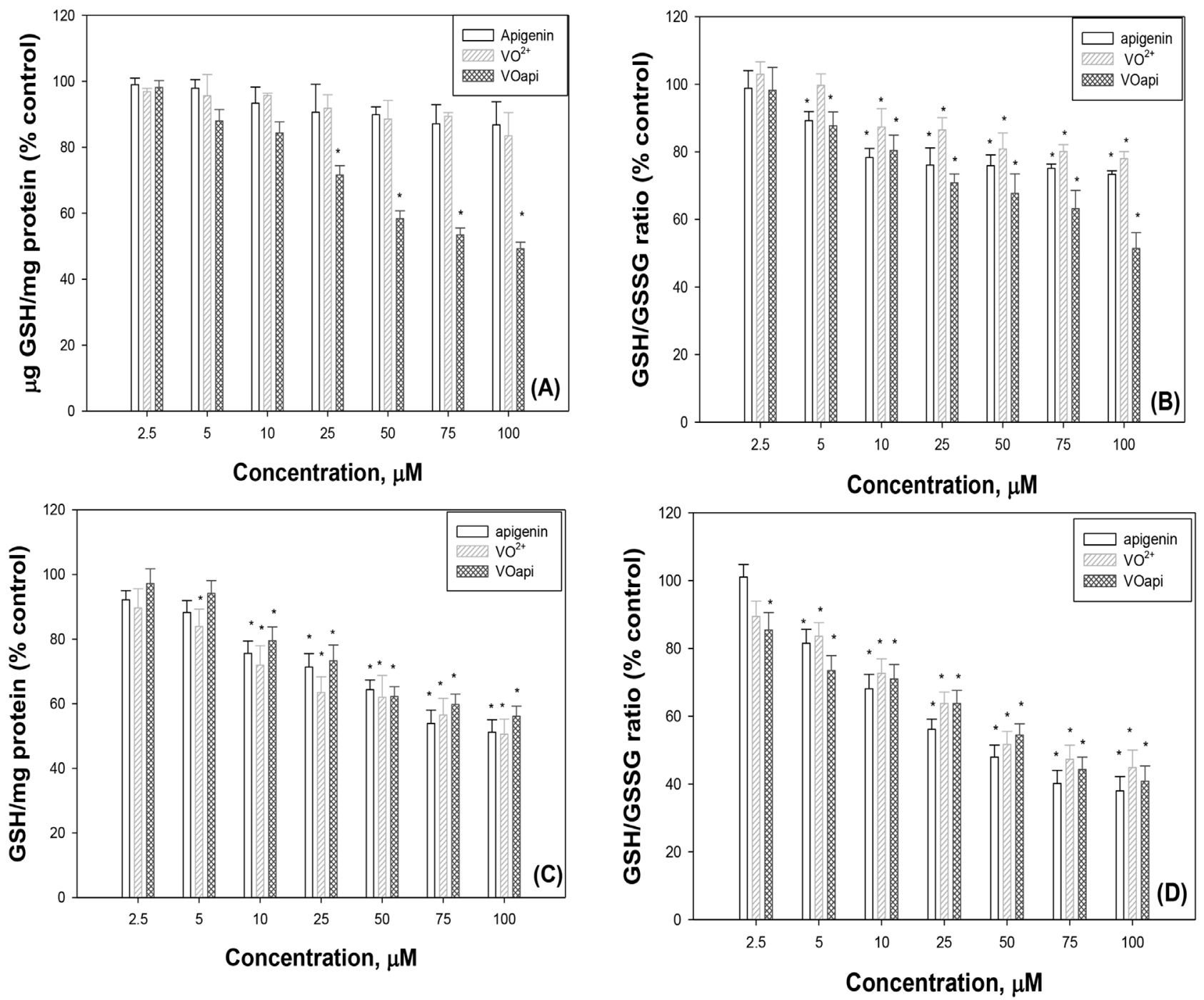

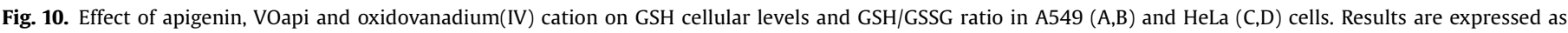
mean \pm SEM of three independent experiments, ${ }^{*}$ significant differences in comparison with the control level $(p<0.05)$.

in A549 and HeLa cells pretreated with different concentrations of compounds and the GSH/GSGG ratio was calculated because GSH depletion by itself is not a major cause of cytotoxicity. From (Fig. 10A) it can be seen that the GSH levels were reduced by ca. $13 \%, 17 \%$ and $52 \%$ relative to the untreated A549 cells in the presence of $100 \mu \mathrm{M}$ of apigenin, oxidovanadium(IV) cation and VOapi, respectively $(\mathrm{p}<0.05)$. The results obtained for apigenin are in agreement with those previously reported $[12,64]$.

On HeLa cells the compounds decreased ca. 50\% the GSH levels (Fig. 10C). As can be seen from Fig. 10B and D, apigenin, oxidovanadium(IV) cation and VOapi induced a decrease in the $\mathrm{GSH} / \mathrm{GSSG}$ ratio in both cell lines. In the A549 cell line the effect of the complex was more pronounced than that of the parent drugs, though ROS production and cell viability were similar for the ligand and the complex. The results indicate that the decrease of the GSH/GSSG ratio was due not only to a decrease in the level of GSH but also to an accumulation of GSSG.

The antioxidant enzymes as superoxide dismutase, catalase, glutathione peroxidase, thioredoxin and glutaredoxin play important roles in removing ROS and maintaining the redox state in cells. In addition, many hydrophilic radical scavengers such as ascorbate (vitamin C) and lipophilic radical scavengers like $\alpha$-tocopherol (vitamin E) protect cells from oxidative damage caused by ROS
$[65,66]$. On the basis of the cellular generation of ROS and the decrease of the cellular GSH/GSSG ratio produced by the compounds, we assumed that the oxidative stress may play a key role in their toxic effects. To confirm this hypothesis we studied the effect of apigenin and VOapi on cell viability in the presence of a mixture of vitamins $C$ and $E$ (Fig. 11) and the effect of NAC on the level of ROS (Fig. 12) generated by the compounds in the cultures of both cell lines. It can be seen that when the cells were incubated in the presence of natural antioxidants the treated-cell viability was recovered. On the other hand, pretreatment of both cell lines with $5 \mathrm{mM}$ of NAC and apigenin or VOapi suppressed the generation of ROS in the A549 cell lines, and reduced the levels of ROS in treatedHeLa cells with respect to the untreated cells. Then, it can be demonstrated that oxidative stress is involved in the cell death mechanism.

\subsubsection{Morphological changes}

A549 and HeLa cells exposed to $100 \mu \mathrm{M}$ of VOapi for $24 \mathrm{~h}$ showed morphological changes, evidenced by condensation of cytoplasm and presence of pyknotic nuclei. VOapi at concentration $10 \mu \mathrm{M}$ did not have an apparent effect compared to untreated control in both cell lines (Fig. 13). These results agree with the effects observed in the viability assay. 

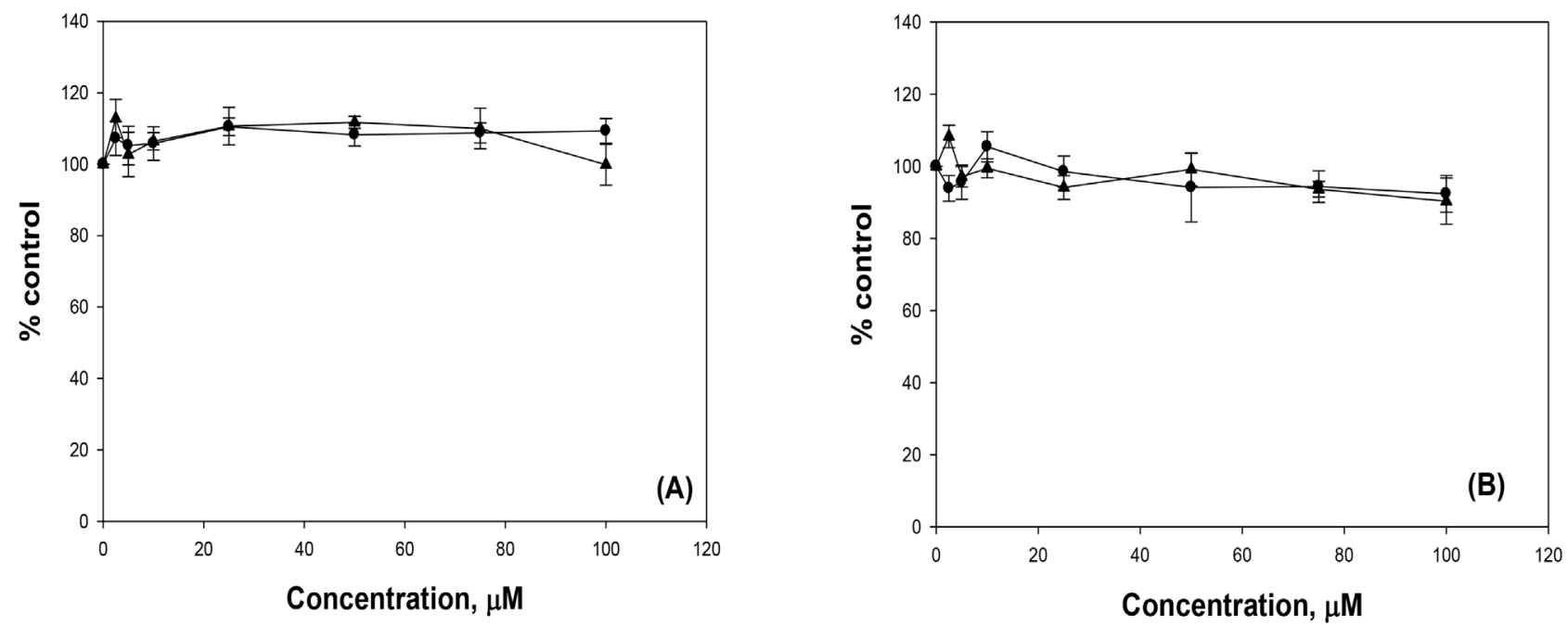

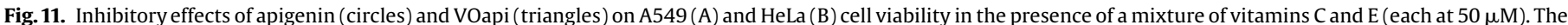

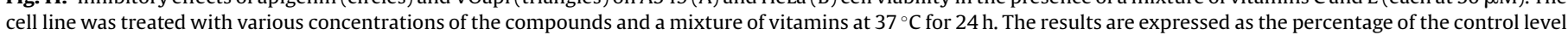

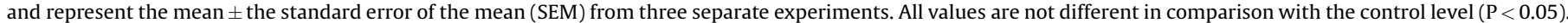
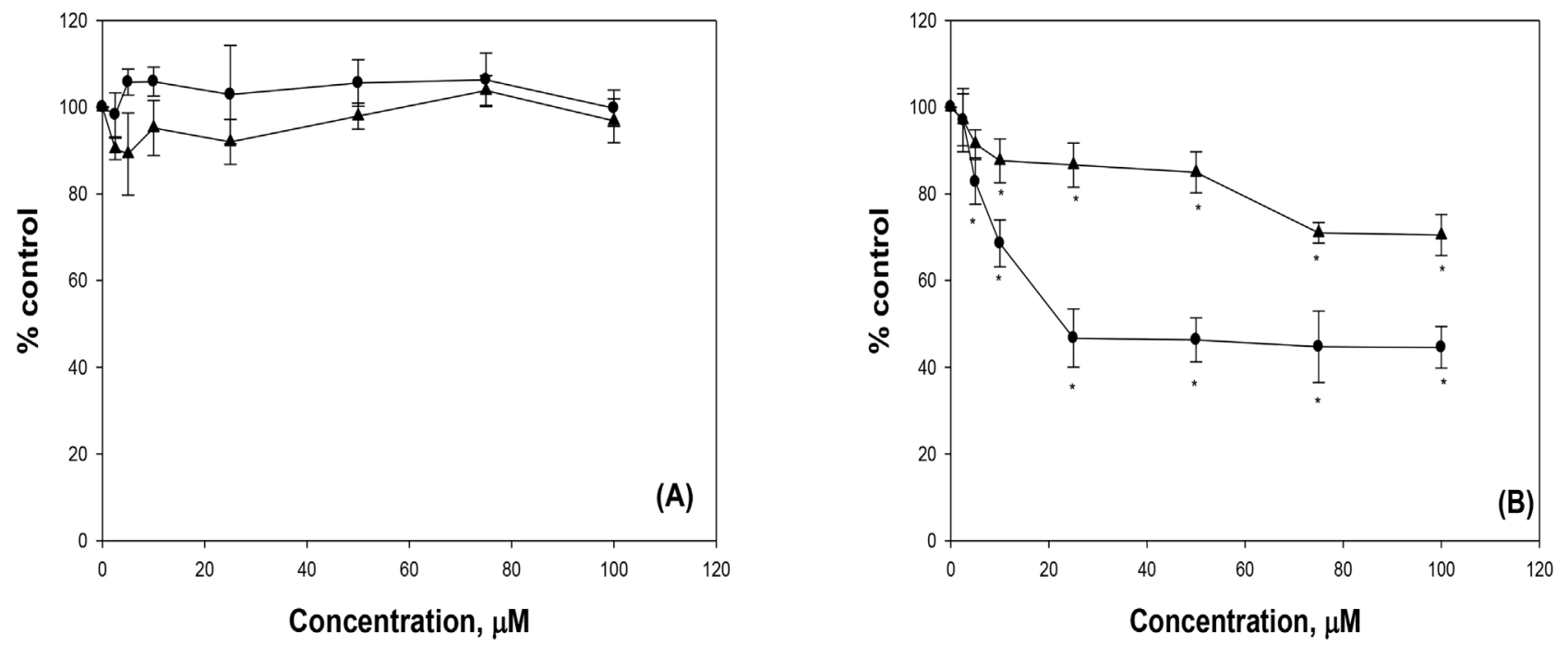

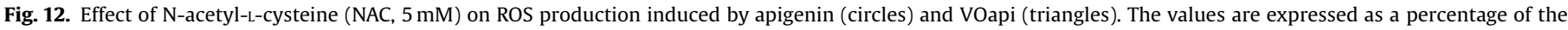
control level and represent the mean \pm SEM. * significant values in comparison with the control level $(\mathrm{P}<0.05)$.

In the present study, we found that apigenin and VOapi displayed a significantly inhibitory effect on the human lung and human cervix cancer cell viability particularly at $48 \mathrm{~h}$ incubation time. One of the possible mechanisms of action by which the compounds induce cell death involved oxidative stress with an increase in the cellular ROS levels that could cause GSH depletion producing cellular redox imbalance.

\subsection{Toxicological assays}

\subsubsection{Artemia salina tests}

The Artemia salina L. test is useful for the screening of novel drugs in order to predict their toxicity and has shown a good correlation $(\mathrm{r}=0.85 \mathrm{p}<0.05)$ with the assays in mice, suggesting that the brine shrimp bioassay is a useful alternative model [67]. The mortality of brine shrimp for every concentration of $\mathrm{VOCl}_{2}$ was previously reported [14], and it has been shown that it increased in a dose-response manner with a $\mathrm{LC}_{50}$ value (dose required to kill half of the members of the tested population, $244 \mu \mathrm{M}$ ). On the other hand, dead nauplii were not observed for the ligand apigenin and the VOapi complex at the tested concentrations showing that the flavonoid and the complex did not exert toxic effects at concentrations up to $300 \mu \mathrm{g} \mathrm{mL}^{-1}$.

\subsubsection{Ames test}

The Ames Salmonella typhimurium assay has been used to identify substances that can produce genetic damage that leads to gene mutations. The test uses Salmonella strains with preexisting mutations that are not capable to synthesize histidine, and then are not able to grow or form colonies in its absence. Compounds with mutagenic potential may restore the genes function (reversion assay). Consequently, a positive test indicates that the compound is mutagenic and therefore may act as a carcinogen. A sample was considered positive when the mutagenic index (MI) was equal or greater than 2 for at least one of the tested doses and if it had a reproducible dose-response curve [37]. It can be seen in Table 5 that the oxidovanadium(IV) cation, the ligand apigenin and the VOapi complex did not exert mutagenic action on the tested 
(a)

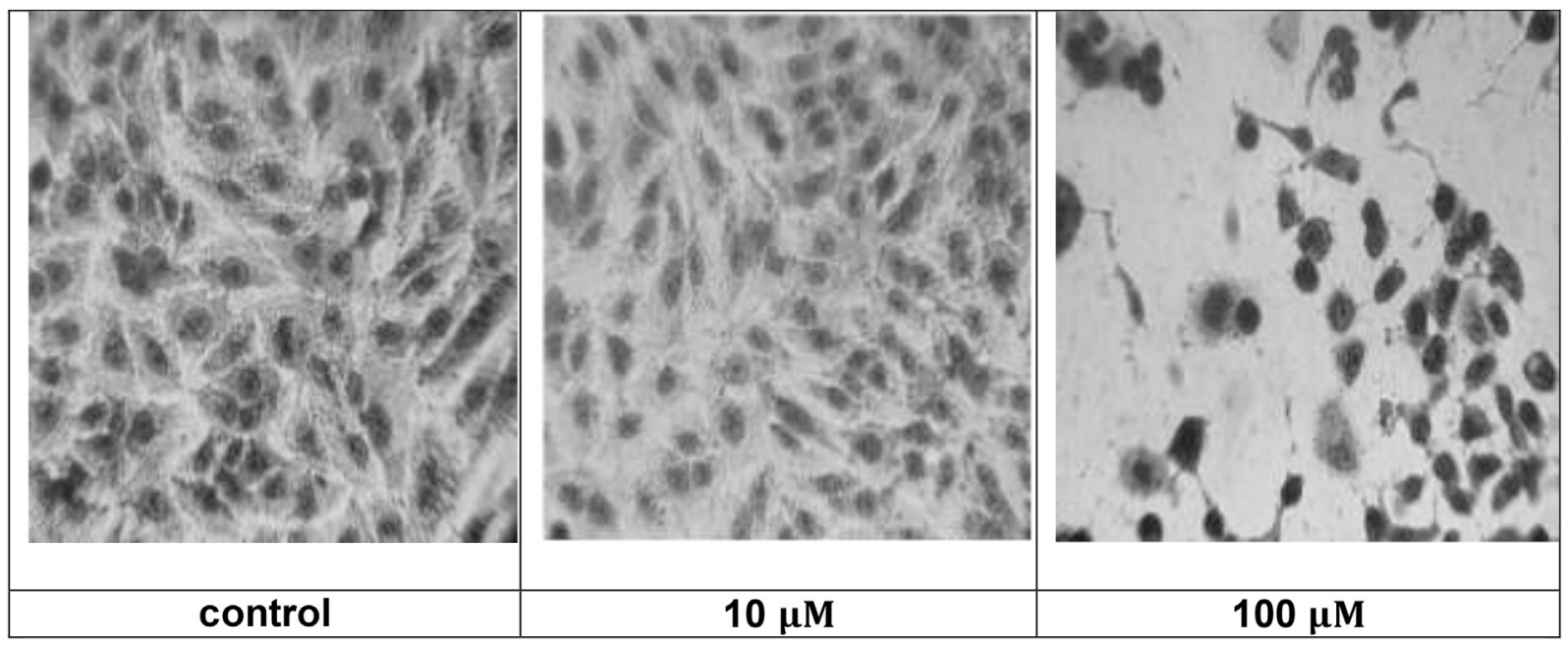

(b)

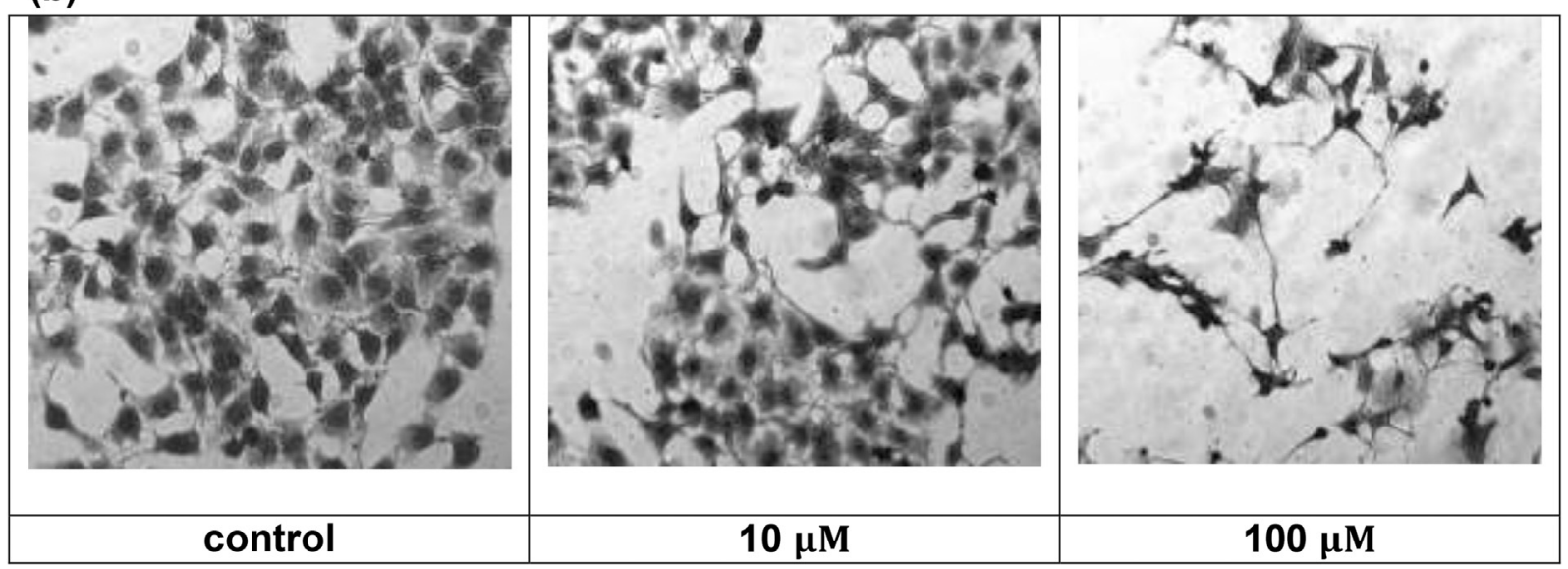

Fig. 13. Effect on cell morphology of the treatment of (a) A549 and (b) HeLa cell line with VOapi. Cells were incubated for $24 \mathrm{~h}$ without drug addition (control) and with VOapi (10 and $100 \mu \mathrm{M}, 40 \times$ ).

Table 5

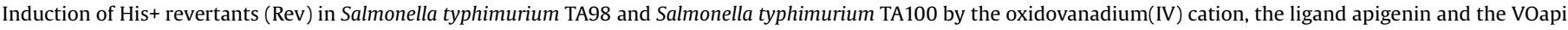
complex without metabolic activation (S9 mix).

\begin{tabular}{|c|c|c|c|c|c|}
\hline \multirow[t]{2}{*}{ Compounds } & \multirow[t]{2}{*}{ Concentration ( $\mu$ g/plate) } & \multicolumn{2}{|c|}{ S. typhimurium TA98 } & \multicolumn{2}{|c|}{ S. typhimurium TA100 } \\
\hline & & Rev/plate ${ }^{a}$ & $\mathrm{MI}^{\mathrm{b}}$ & Rev/plate ${ }^{\mathrm{a}}$ & $\mathrm{MI}^{\mathrm{b}}$ \\
\hline Strain control & & $34.5 \pm 0.5^{c}$ & - & $139.5 \pm 1.5$ & - \\
\hline \multirow{3}{*}{$\mathrm{VOCl}_{2}$} & 75 & $26 \pm 3^{c}$ & $0.75^{\mathrm{c}}$ & - & - \\
\hline & 37.5 & $30 \pm 2^{c}$ & $0.87^{c}$ & - & - \\
\hline & 18.8 & $30 \pm 2^{c}$ & $0.87^{\mathrm{c}}$ & $97.5 \pm 2.5$ & 0.70 \\
\hline Strain control & & $22.5 \pm 1.5$ & - & $100.5 \pm 1.5$ & - \\
\hline \multirow[t]{5}{*}{ Apigenin } & 300 & - & - & $69 \pm 2$ & 0.69 \\
\hline & 150 & $23 \pm 2$ & 1.02 & $80.5 \pm 1.5$ & 0.80 \\
\hline & 75 & $24 \pm 1$ & 1.07 & $96 \pm 2$ & 0.95 \\
\hline & 37.5 & $17 \pm 1$ & 0.75 & $91.5 \pm 1.5$ & 0.91 \\
\hline & 18.75 & $20.5 \pm 1.5$ & 0.91 & $76 \pm 2$ & 0.76 \\
\hline \multirow[t]{5}{*}{ VOapi } & 300 & - & - & $64 \pm 1$ & 0.64 \\
\hline & 150 & $13.5 \pm 1.5$ & 0.60 & $59.5 \pm 1.5$ & 0.59 \\
\hline & 75 & $18 \pm 2$ & 0.80 & $74 \pm 1$ & 0.74 \\
\hline & 37.5 & $14.5 \pm 1.5$ & 0.64 & $68 \pm 2$ & 0.68 \\
\hline & 18.8 & $18 \pm 1$ & 0.80 & $73 \pm 1$ & 0.73 \\
\hline
\end{tabular}

a Number of revertants/plate: mean of two independent experiments \pm SD.

${ }^{b}$ MI: mutagenic index (number of His+ induced in the sample/number of spontaneous His+ in the negative control).

c Taken from ref [14]. 
strains. For oxidovanadium(IV) cation the MI could not be determined at concentrations higher than $75 \mu \mathrm{g} /$ plate and $18.75 \mu \mathrm{g} /$ plate due to the antimicrobial action exerted by $\mathrm{VOCl}_{2}$ against Salmonella typhimurium TA98 and Salmonella typhimurium TA100, respectively. The ligand apigenin and the VOapi complex showed antimicrobial activity against Salmonella typhimurium TA98 at concentrations higher than $150 \mu \mathrm{g} /$ plate. The absence of mutagenic activity of $\mathrm{VOCl}_{2}$ in the Ames test employing Salmonella typhimurium TA98 was previously reported [14]. The mutagenic index value resulted lower than 2 in all the cases showed that the tested substances could not induce an increase in the number of revertants. These results indicated that the tested compounds did not induce frameshift mutations (S. typhimurium TA98) or basepair substitution mutations (S. typhimurium TA100) at the tested concentrations.

\subsection{Bovine serum albumin (BSA) interaction}

\subsubsection{Fluorescence quenching studies}

The interaction between biomacromolecules, especially those between plasma proteins and drugs, has been an interesting research field in life sciences, chemistry, and clinical medicine. Bovine serum albumin (BSA) is used as the model protein for drug delivery because of its medical importance, abundance, low cost, ease of purification, unusual ligand-binding properties and that it is widely accepted in the pharmaceutical industry. The studies concerning the interaction and potential transport with bovine serum albumin were performed with apigenin and VOapi measuring the fluorescence intensity of the BSA before and after the addition of these compounds. The interaction with oxidovanadium(IV) cation was previously discussed [38]. A strong fluorescence emission of BSA assigned to the two tryptophan residues of the protein (located at positions 134 and 212, respectively) that possess intrinsic fluorescence has been displayed (Fig. 14) [68]. The effects of apigenin and VOapi complex on the intrinsic BSA fluorescence are shown in Fig. 14. For both compounds the fluorescence intensities of BSA decreased with the increase of the concentration, accompanied by a slight blue-shift of the maximum emission wavelengths in the fluorescence spectra suggesting that the binding is possibly associated with changes in the dielectric environment of at least one of the two indole rings in BSA [69].

To confirm the quenching mechanism the fluorescence data at different temperatures have been analyzed with the Stern-Volmer Eq. (1) [70]:

$\mathrm{F}_{0} / \mathrm{F}=1+\mathrm{K}_{\mathrm{q}} \tau_{\mathrm{o}}[\mathrm{Q}]=1+\mathrm{K}_{\mathrm{SV}}[\mathrm{Q}]$

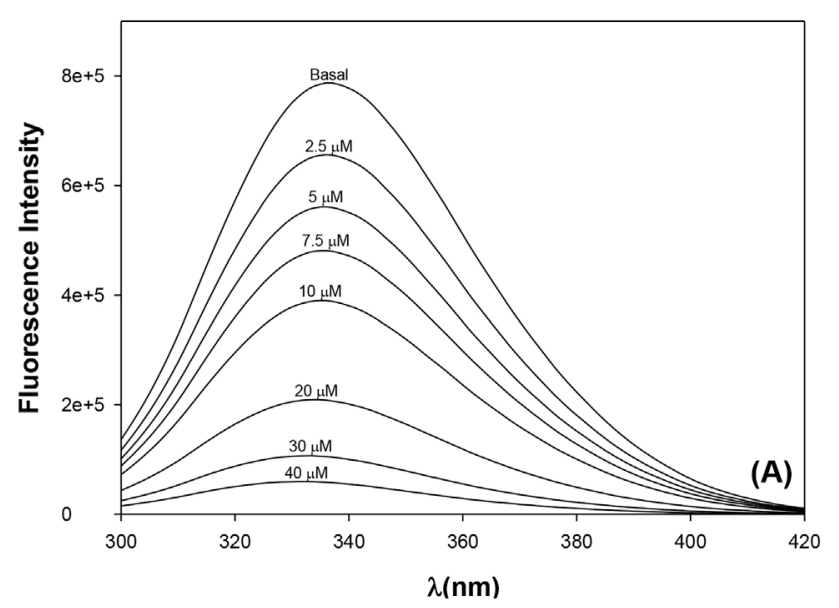

where $F_{0}$ and $F$ are the fluorescence intensities in the absence and presence of quencher, respectively; $\mathrm{K}_{\mathrm{q}}$ is the bimolecular quenching constant; $\tau_{0}$ is the lifetime of the fluorophore in the absence of quencher; [Q] is the concentration of quencher and $K_{s v}$ is the SternVolmer quenching constant which can be obtained from the slope of eq. (1). Fig. 15 displays the Stern-Volmer plots of the quenching of BSA fluorescence by apigenin (Fig. 15A) and VOapi (Fig. 15B) at different temperatures. It can be observed that the plots largely deviated from linearity toward the y-axis at concentrations higher than $10 \mu \mathrm{M}$. The upward curvature indicated that the quenching type is a combined quenching (both static and dynamic) [70] but at lower concentrations a single quenching (static or dynamic) probably takes place. The Stern-Volmer plots were used to elucidate these assumptions at lower concentrations, and a linear correlation has been obtained for both compounds (insets, Fig. 15C and $\mathrm{D}$, respectively). In Table 6 the calculated values of $\mathrm{K}_{\mathrm{sv}}$ are presented showing a decrease with temperature. When the bimolecular quenching constants $\mathrm{K}_{\mathrm{q}}$ are calculated using the well-known relationship ( $\mathrm{Kq}=\mathrm{Ksv} / \tau_{0}, \tau_{0}=10^{-8} \mathrm{~s}$, Table 6$)$, values much greater than the maximum dynamic quenching constant $2.0 \times 10^{10} \mathrm{M}^{-1} \mathrm{~s}^{-1}$ have been obtained. These results suggested that the interaction between the compounds and BSA most probably occurred by static quenching [70].

\subsubsection{Binding constants and the number of binding sites}

The determination of the level of compound binding with serum albumin is critical and will directly correlate with the transport, disposition, and in vivo efficacy of the compound. The value of the binding constant, $\mathrm{K}_{\mathrm{a}}$, is essential to understand the distribution of compounds in plasma since a weak binding can result in comparatively high concentrations of the drug in the plasma, resulting in a shorter life time while a strong binding can decrease the concentrations of compound in plasma, improving the pharmacological effect. On the assumption that the fluorescence quenching of protein could be a static quenching process (complex formation between protein and quencher), the equilibrium between free and bound molecule could be given by the following Eq. (2):

$$
\log \left[\left(\mathrm{F}_{0}-\mathrm{F}\right) / \mathrm{F}\right]=\log \mathrm{K}_{\mathrm{a}}+\mathrm{n} \log [\mathrm{Q}]
$$

where $n$ is the number of binding sites. The $K_{a}$ and $n$ values at different temperatures acquired from the plots shown in Fig. 16 are listed in Table 6 . It was found that the binding constant decreased with an increase in temperature, resulting in a reduction of the stability of the compound-BSA system. Comparing the binding constants of apigenin-BSA and VOapi-BSA systems, it was found

Fig. 14. The fluorescence spectra of BSA at various concentrations of apigenin (A) and VOapi (B). $\lambda_{\mathrm{ex}}=280 \mathrm{~nm}$, $[\mathrm{BSA}]=6 \mu \mathrm{M}, \mathrm{T}=298 \mathrm{~K}$. 


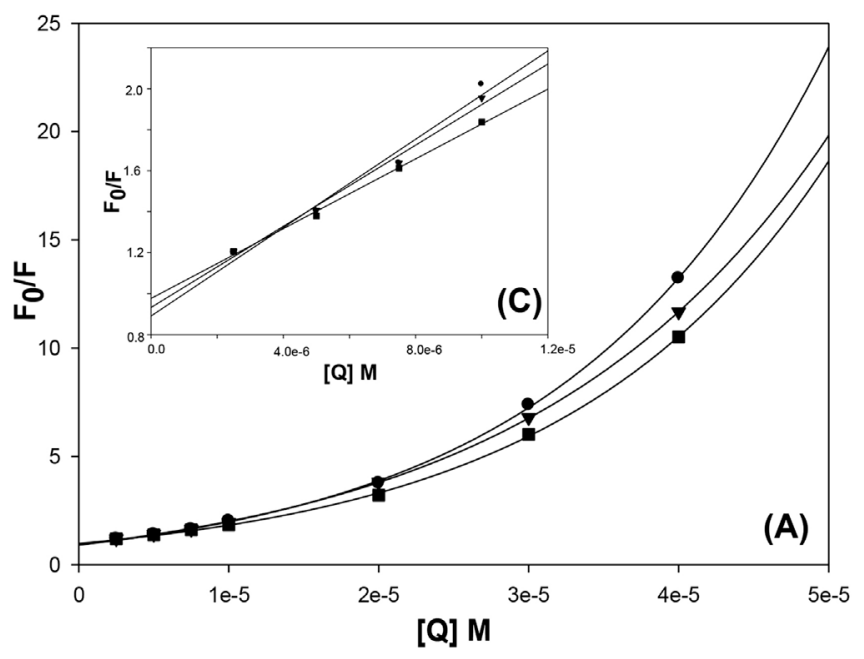

Fig. 15. Plots of $F_{0} / F$ vs $[Q]$ for $B S A$ with apigenin $(A)$ and VOapi $(B)$ at different temperatures ( and VOapi (D) at concentrations of $2.5 \times 10^{-6}, 5 \times 10^{-6}, 7.5 \times 10^{-6}$ and $1 \times 10^{-5} \mathrm{M}$.

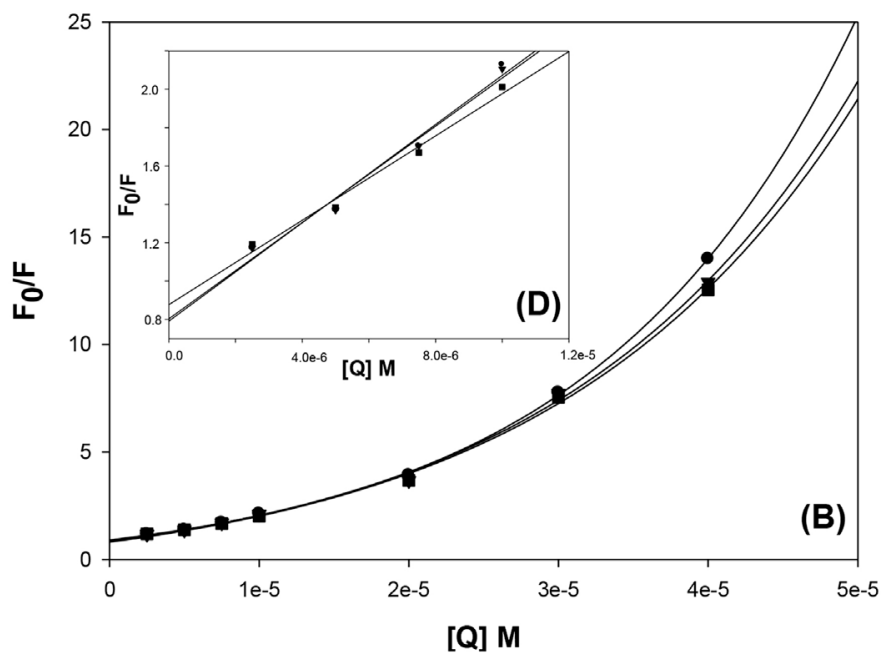

$298 \mathrm{~K} ;(\boldsymbol{\nabla}), 303 \mathrm{~K}$

), $310 \mathrm{~K}), \lambda_{\mathrm{ex}}=280 \mathrm{~nm}$. Inset: $\mathrm{F}_{0} / \mathrm{F}$ vs [Q] of apigenin (C)

Table 6

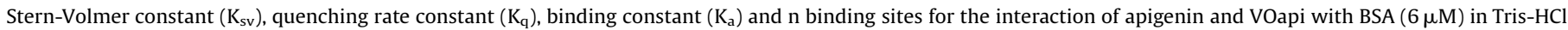
buffer (0.1 M, pH 7.4).

\begin{tabular}{|c|c|c|c|c|c|c|}
\hline Compounds & $\mathrm{T}(\mathrm{K})$ & $\mathrm{K}_{\mathrm{sv}}\left(\mathrm{x} 10^{4}\right)\left(\mathrm{M}^{-1}\right)$ & $r^{2}$ & $\mathrm{~K}_{\mathrm{q}}\left(\mathrm{x} 10^{12}\right)\left(\mathrm{M}^{-1} \mathrm{~s}^{-1}\right)$ & $K_{a}\left(x 10^{5}\right)\left(M^{-1}\right)$ & $\mathrm{n}$ \\
\hline \multirow[t]{3}{*}{ apigenin } & 298 & $10.71 \pm 0.10$ & 0.98 & $10.71 \pm 0.10$ & $5.22 \pm 0.24$ & $1.15 \pm 0.01$ \\
\hline & 303 & $9.77 \pm 0.19$ & 0.99 & $9.77 \pm 0.19$ & $2.50 \pm 0.06$ & $1.09 \pm 0.01$ \\
\hline & 310 & $8.43 \pm 0.11$ & 0.99 & $8.43 \pm 0.11$ & $0.75 \pm 0.33$ & $0.99 \pm 0.04$ \\
\hline \multirow[t]{3}{*}{ VOapi } & 298 & $12.89 \pm 0.18$ & 0.99 & $12.89 \pm 0.18$ & $150.41 \pm 7.59$ & $1.43 \pm 0.01$ \\
\hline & 303 & $12.47 \pm 0.11$ & 0.99 & $12.47 \pm 0.11$ & $51.16 \pm 3.16$ & $1.34 \pm 0.01$ \\
\hline & 310 & $11.15 \pm 0.21$ & 0.98 & $11.15 \pm 0.21$ & $5.88 \pm 4.63$ & $1.14 \pm 0.07$ \\
\hline
\end{tabular}

$\mathrm{r}^{2}$ is the correlation coefficient for the $\mathrm{K}_{\mathrm{SV}}$ values.
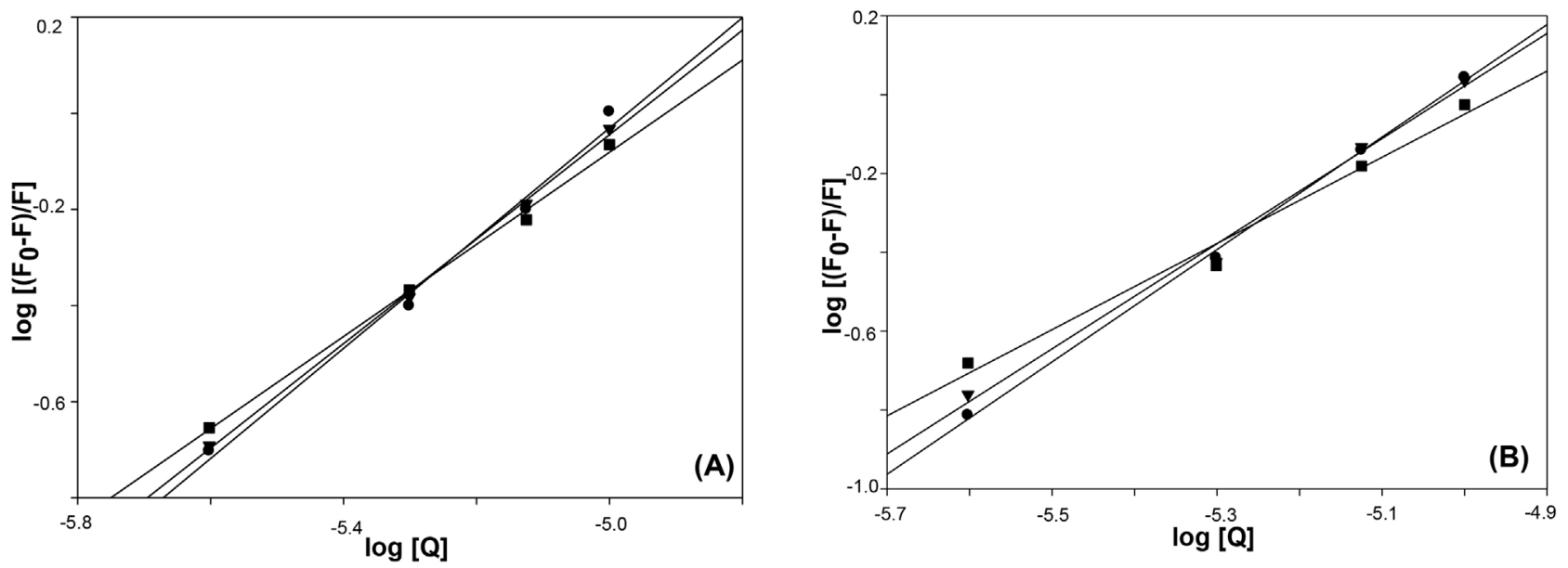

Fig. 16. Plots of $\log \left[\left(F_{0}-F\right) / F\right]$ vs. $\log [Q]$ for the apigenin-BSA system $(A)$ and VOapi-BSA system $(B):(\bullet), 298 \mathrm{~K} ;(\boldsymbol{\nabla}), 303 \mathrm{~K} ;(\boldsymbol{\square}), 310 \mathrm{~K},[\mathrm{BSA}]=6 \mu \mathrm{M}, \lambda_{\text {ex }}=280$.

that the complex binds to BSA relatively stronger than the free ligand. The number of binding sites of the compounds with BSA $(\mathrm{n}=0.99-1.43$ ) was $\mathrm{ca}$. 1.0 and corresponded to the binding sites with high affinity. The obtained binding constants are in the intermediate range so that they are not too low to prevent efficient distribution and are not so high to lead to decreased plasma concentration. These data suggested that apigenin and VOapi can be stored and removed by BSA. Our results for $K_{s v}, K_{a}$, $n$ and the thermodynamic parameters (negative values of $\Delta \mathrm{H}$ and $\Delta \mathrm{S}$, see below) agree with previous data reported for apigenin [71]. On the other hand, it is important to mention that there are some discrepancies in the literature for the interaction of apigenin with bovine serum albumin being the $\mathrm{K}_{\mathrm{sv}}, \mathrm{K}_{\mathrm{a}}$ or the thermodynamic parameters quite different from each other [72-74]. These differences have been attributed to the different experimental conditions used in each determination [74] (differences in albumin and flavonoid concentrations, albumin fractions and/or dissolution media: $\mathrm{pH}$ values and the concentrations of $\mathrm{NaCl}$ and $\mathrm{Mg}^{2+}$ ).

\subsubsection{Thermodynamic parameters}

The interaction forces between drugs and biomolecules may include electrostatic interactions, multiple hydrogen bonds, van 
der Waals interactions, hydrophobic and steric contacts within the antibody-binding site, etc [75]. To infer the type of process of the interaction between apigenin and VOapi with BSA, thermodynamic parameters, including enthalpy change $(\Delta \mathrm{H})$, entropy change $(\Delta S)$ and free energy change $(\Delta G)$ were investigated. If $\Delta$ H does not vary significantly over the temperature range studied, then its value and that of $\Delta \mathrm{S}$ can be evaluated from the van't Hoff Eq. (3):

$\ln \mathrm{K}_{\mathrm{a}=}-\Delta \mathrm{H} / \mathrm{RT}+\Delta \mathrm{S} / \mathrm{R}$

where $\mathrm{K}_{\mathrm{a}}$ is analogous to the associative binding constants at the corresponding temperature and $\mathrm{R}$ is the gas constant. The free energy change $(\Delta G)$ is then estimated from the following relationship (4):

$\Delta \mathrm{G}=\Delta \mathrm{H}-\mathrm{T} \Delta \mathrm{S}$

The negative sign obtained for $\Delta \mathrm{G}$ (Table 7 ) indicated a spontaneous interaction process. The negative enthalpy change suggested that the binding between the compounds and BSA was exothermic and then the association constant decrease with increasing temperature [75].

An important source of a negative contribution to $\Delta \mathrm{H}$ and $\Delta \mathrm{S}$ will arise if a hydrogen bond is formed and furthermore the interactions involving delocalized electrons of aromatic ring systems make significant contributions to their negative sign. The negative $\Delta \mathrm{H}$ and $\Delta \mathrm{S}$ values obtained for the interaction of apigenin and VOapi with BSA indicated that the binding is mainly enthalpy driven with an unfavorable entropic factor and therefore the hydrogen bonding and van der Waals forces played major roles during the interactions [75].

An interaction between BSA and metal complexes often leads to a perturbation of the secondary structure of the protein, by disrupting the disulfide bonds and leading to a partial loss of $\alpha$-helix conformation with the subsequent unfolding of the protein, or a change in the polarity of the environment to which the tryptophan residues are exposed, as a result of molecular interactions, such as excited-state reactions, molecular rearrangements, energy transfer, ground-state complex formation or collision quenching [76]. For the VOapi complex, a BSA-complex formation interaction has been determined. A similar interaction has been assumed for the oxidovanadium(IV) complexes of luteolin [51] and baicalin [14] with an interaction that favors BSA complex formation and binding constant values of similar magnitude order $\left(79.4 \times 10^{6} \mathrm{M}^{-1}\right.$ and $13.5 \times 10^{6} \mathrm{M}^{-1}$, respectively). Furthermore, it has been determined that the reversible binding occurs through one of the high affinity sites of the albumin $(n=1.5-$ 1.3) [77]. for all the measured VOflavonoid complexes.

\section{Conclusions}

A new oxidovanadium(IV) metal complex with the flavonoid apigenin has been synthesized and characterized by elemental analysis, spectroscopic techniques, thermal and computational studies. In vitro cytotoxicity testing showed that the compounds exhibit significant cytotoxicity towards tumor cell lines, especially

Table 7

Thermodynamic parameters for the interactions between apigenin and VOapi with BSA.

\begin{tabular}{llll}
\hline Compounds & $\Delta \mathrm{H}(\mathrm{KJ} / \mathrm{mol})$ & $\Delta \mathrm{S}(\mathrm{J} / \mathrm{mol})$ & $\Delta \mathrm{G}(\mathrm{KJ} / \mathrm{mol})$ \\
\hline apigenin & -124.62 & -308.46 & $-32.70(298 \mathrm{~K})$ \\
& & $-31.16(303 \mathrm{~K})$ \\
VOapi & & $-29.00(310 \mathrm{~K})$ \\
& -209.35 & -564.15 & $-41.23(298 \mathrm{~K})$ \\
& & $-38.41(303 \mathrm{~K})$ \\
& & $-34.46(310 \mathrm{~K})$ \\
\hline
\end{tabular}

for the HeLa cell line, they did not exert toxic effects against Artemia salina and did not behave as mutagenic agents indicating that these compounds have the potential to act as effective metalbased anticancer drugs. According to the structural features of apigenin it exerted mild antioxidant activities. However, in cultured cells the levels of ROS are increased and GSH and GSH/ GSSG depletion could be observed in parallel with the decreased cell viability (more effective in the HeLa cell line), suggesting a stress oxidative mechanism of cell-killing. Moreover, the compounds could be stored and transported by bovine serum albumin interacting by complex formation between protein and quencher through hydrogen bonding and van der Waals forces. A similar interaction has previously been determined for other VOflavonoid complexes and the binding constants of these complexes displayed the same order of magnitude.

\section{Acknowledgements}

This work was supported by UNLP, CICPBA, CONICET, CAI + DUNL, PIP 0611 and ANPCyT (PICT 2013-0569, 2014-1742), Argentina. EGF, LGN, NBO are research fellows of CONICET. PAMW is a research fellow of CICPBA, Argentina. JJMM and ALP are fellowship holders from CONICET.

\section{Appendix A. Supplementary data}

Supplementary data associated with this article can be found, in the online version, at 10.1016/j.jphotochem.2017.05.007.

\section{References}

[1] International Agency for Research on Cancer Globocan, Estimated Cancer Incidence, Mortality and Prevalence Worldwide in 2012, (2012). Available online: http://www.globocan.iarc.fr.

[2] M.A. Moga, O.G. Dimienescu, C.A. Arvatescu, A. Mironescu, L. Dracea, L. Ples The role of natural polyphenols in the prevention and treatment of cervical cancer-an overview, Molecules 21 (2016) 1-32.

[3] H. ZurHausen, Papilloma viruses causing cancer: evasion from host-cell control in early events in carcinogenesis, J. Natl. Cancer Inst. 92 (2000) 690698.

[4] A. Nagappan, H.J. Lee, V.V.G. Saralamma, H.S. Park, G.E. Hong S. Yumnam, S. Raha, S.N. Charles, S.C. Shin, E.H. Kim, W.S. Lee, G.S. Kim, Flavonoids isolated from Citrus platymamma induced G2/M cell cycle arrest and apoptosis in A549 human lung cancer cells, Oncol. Lett. 12 (2016) 1394-1402.

[5] S. Kumar, A.K. Pandey, Chemistry and biological activities of flavonoids: an overview, Sci. World J. 2013 (2013) 1-16.

[6] S. Shukla, S. Gupta, Apigenin: a promising molecule for cancer prevention, Pharm. Res. 27 (2010) 962-978.

[7] Z. Li, X. Hua, Y. Wang, J. Fang, Apigenin inhibits proliferation of ovarian cancer A2780 cells through Id1, FEBS Lett. 583 (2009) 1999-2003.

[8] M. Zhao, J. Ma, H. Zhu, X. Zhang, Z. Du, Y. Xu, X. Yu, Apigenin inhibits proliferation and induces apoptosis in human multiple myeloma cells through targeting the trinity of CK2, Cdc37 and Hsp90, Mol. Cancer 10 (2011) 104-118.

[9] H. Lu, Y. Chie, M. Yang, C. Lee, J. Fu, J. Yang, T. Tan, S. Wu, Y. Ma, M. Ip, J. Chung Apigenin induces caspase-dependent apoptosis in human lung cancer A549 cells through Bax- and Bcl-2-triggered mitochondrial pathway, Int. J. Oncol. 36 (2010) 1477-1484.

[10] G. Valdameri, M. Trombetta-Lima, P.R. Worfel, A.R.A. Pires, G.R. Martinez, G.R Noleto, S.M.S.C. Cadena, M.C. Sogayar, S.M.B. Winnischofer, M.E.M. Rocha, Involvement of catalase in the apoptotic mechanism induced by apigenin in HepG2 human hepatoma cells, Chem.-Biol. Interact. 193 (2011) 180-189.

[11] S.H. Lee, J.K. Ryu, K.Y. Lee, S.M. Woo, J.K. Park, J.W. Yoo, Y.T. Kim, Y.B. Yoon, Enhanced anti-tumor effect of combination therapy with gemcitabine and apigenin in pancreatic cancer, Cancer Lett. 259 (2008) 39-49.

[12] S. Das, J. Das, A. Samadder, N. Boujedaini, A.R. Khuda-Bukhsh, Apigenininduced apoptosis in A375 and A549 cells through selective action and dysfunction of mitochondria, Exp. Biol. Med. 237 (2012) 1433-1448.

[13] M.E. Harrison, M.R. Power Coombs, L.M. Delaney, D.W. Hoskin, Exposure of breast cancer cells to a subcytotoxic dose of apigenin causes growth inhibition oxidative stress, and hypophosphorylation of Akt, Exp. Mol. Pathol. 97 (2014) 211-217.

[14] J.J. Martínez Medina, L.G. Naso, A.L. Pérez, A. Rizzi, E.G. Ferrer, P.A.M. Williams, Antioxidant and anticancer effects and bioavailability studies of the flavonoid baicalin and its oxidovanadium(IV) complex, J. Inorg. Biochem. 166 (2017) 150-161 and references therein. 
[15] M. Onishi, Photometric Determination of Traces of Metals, Part II, 4th ed. Wiley, NewYork, 1998.

[16] S. Stoll, A. Schweiger, EasySpin, a comprehensive software package for spectral simulation and analysis in EPR, J. Magn. Reson. 178 (2006) 42-55.

[17] W.J. Geary, The use of conductivity measurements in organic solvents for the characterisation of coordination compounds, Coord. Chem. Rev 7 (1971) 81122.

[18] W. Kohn, L.J. Sham, Self-consistent equations including exchange and correlation effects, Phys. Rev. 140 (1965) A1133-A1138.

[19] P. Hohenberg, W. Kohn, Inhomogeneous electron gas, Phys. Rev. 136 (1964) B864-B871.

[20] R.G. Parr, W. Yang, Density Functional Theory of Atoms, Molecules, Oxford University Press Clarendon Press, Oxford; New York, 1989.

[21] M.J. Frisch, G.W. Trucks, H.B. Schlegel, G.E. Scuseria, M.A. Robb, J.R. Cheeseman, G. Scalmani, V. Barone, B. Mennucci, G.A. Petersson, H. Nakatsuji, M. Caricato, X. Li, H.P. Hratchian, A.F. Izmaylov, J. Bloino, G. Zheng, J.L. Sonnenberg, M. Hada, M. Ehara, K. Toyota, R. Fukuda, J. Hasegawa, M. Ishida, T. Nakajima, Y. Honda, O. Kitao, H. Nakai, T. Vreven, J.A. Montgomery, Jr., J.E. Peralta, F. Ogliaro, M. Bearpark, J.J. Heyd, E. Brothers, K.N. Kudin, V.N. Staroverov, T. Keith, R. Kobayashi, J. Normand, K. Raghavachari, A. Rendell, J.C. Burant, S.S. Iyengar, J. Tomasi, M. Cossi, N. Rega, J.M. Millam, M. Klene, J.E. Knox, J.B. Cross, V. Bakken, C. Adamo, J. Jaramillo, R. Gomperts, R.E. Stratmann, O. Yazyev, A.J. Austin, R. Cammi, C. Pomelli, J.W. Ochterski, R.L. Martin, K. Morokuma, V.G. Zakrzewski, G.A. Voth, P. Salvador, J.J. Dannenberg, S. Dapprich, A.D. Daniels, O. Farkas, J.B. Foresman, J.V. Ortiz, J. Cioslowski, D.J. Fox, Gaussian 09, Revision B.01, Gaussian, Inc, Wallingford CT, 2010.

[22] C. Corredor, T. Teslova, M. Vega Cañamares, Z. Chen, J. Zhang, J.R. Lombardi, M Leona, Raman and surface-enhanced Raman spectra of chrysin apigenin and luteolin, Vib. Spectrosc. 49 (2009) 190-195.

[23] A. Amat, F. De Angelis, A. Sgamellottia, S. Fantacci, Theoretical investigation of the structural and electronic properties of luteolin: apigenin and their deprotonated species, J. Mol. Struct. Theochem. 868 (2008) 12-21.

[24] G. Mariappan, N. Sundaraganesan, S. Manoharan, The spectroscopic properties of anticancer drug Apigenin investigated by using DFT calculations, FT-IR FTRaman and NMR analysis, Spectrochim. Acta A Mol. Biomol. Spectrosc. 95 (2012) 86-99.

[25] A.D. Becke, J. Density functional thermochemistry. III. The role of exact exchange, Chem. Phys. 98 (1993) 5648-5652.

[26] R. Krishnan, J.S. Binkley, R. Seeger, J.A. Pople, Self-consistent molecular orbital methods. XX. A basis set for correlated wave functions, J. Chem. Phys 72 (1980) 650-654.

[27] G. Micera, E. Garribba, The effect of the functional basis set, and solvent in the simulation of the geometry and spectroscopic properties of $\mathrm{V}^{\mathrm{IV}} \mathrm{O}^{2+}$ complexes. chemical and biological applications, Int. J. Quantum Chem. 112 (2012) 24862498.

[28] M.H. Jamróz, Vibrational Energy Distribution Analysis, VEDA 4.0 Program Warsaw 2004-2010.

[29] B. Halliwell, J.M.C. Gutteridge, O. Aruoma, The deoxyribose method: a simple test-tube assay for determination of rate constants for reactions of hydroxyl radicals, Anal. Biochem. 165 (1987) 215-219.

[30] W.Y. Huang, K. Majumder, J. Wu, Oxygen radical absorbance capacity of peptides from egg white protein ovotransferrin and their interaction with phytochemicals, Food Chem. 23 (2010) 635-641.

[31] C.D. Hapner, P. Deuster, Y. Chen, Inhibition of oxidative hemolysis by quercetin, but not other antioxidants, Chem. Biol. Interact. 186 (2010) 275-279.

[32] T. Yamaguchi, H. Takamura, T.C. Matoba, J. Terao, HPLC method for evaluation of the free radical-scavenging activity of foods by using 1,1-diphenyl-2picrylhydrazyl, Biosci, Biotechnol. Biochem. 62 (1998) 1201-1204.

[33] L. Ling, K. Tan, H. Lin, G. Chiu, The role of reactive oxygen species and autophagy in safingol-induced cell death, Cell. Death. Dis. 2 (2011) e129.

[34] P.J. Hissin, R. Hilf, A fluorometric method for determination of oxidized and reduced glutathione in tissues, Anal. Biochem. 74 (1976) 214-226.

[35] M. Bradford, A rapid and sensitive method for the quantitation of microgram quantities of protein utilizing the principle of protein-dye binding, Anal. Biochem. 72 (1976) 248-254.

[36] L. Lewan, M. Andersson, P. Morales-Gomez, Use of Artemia salina in toxicity testing, Altern. Lab. Anim. 20 (1992) 297-301.

[37] D.M. Maron, B.N. Ames, Revised methods for the Salmonella mutagenicity test, Mutat. Res. 113 (1983) 173-215.

[38] M.S. Islas, L.G. Naso, L. Lezama, M. Valcarcel, C. Salado, M. Roura-Ferrer, E.G. Ferrer, P.A.M. Williams, Insights into the mechanisms underlying the antitumor activity of an oxidovanadium(IV) compound with the antioxidant naringenin. Albumin binding studies, J. Inorg. Biochem. 149 (2015) 12-24.

[39] E.G. Ferrer, M.V. Salinas, M.J. Correa, L. Naso, D.A. Barrio, S.B. Etcheverry, L Lezama, T. Rojo, P.A.M. Williams, Synthesis characterization, antitumoral and osteogenic activities of quercetin vanadyl(IV) complexes, J. Biol. Inorg. Chem. 11 (2006) 791-801.

[40] Y. Minenkov, Å. Singstad, G. Occhipinti, V.R. Jensen, The accuracy of DFToptimized geometries of functional transition metal compounds: a validation study of catalysts for olefin metathesis and other reactions in the homogeneous phase, Dalton Trans. 41 (2012) 5526-5541.

[41] D. Sanna, V. Ugone, G. Lubinu, G. Micera, E. Garribba, Behavior of the potential antitumor V(IV)O complexes formed by flavonoid ligands. 1. Coordination modes and geometry in solution and at the physiological pH, J. Inorg. Biochem. 140 (2014) 173-184.
[42] R.P. Dodge, D.H. Templeton, A. Zalkin, Crystal structure of vanadyl bisacetylacetonate. geometry of vanadium in fivefold coordination, J. Chem. Phys. 35 (1961) 55-67.

[43] J. Krakowiaka, D. Lundberg, I. Persson, A coordination chemistry study of hydrated and solvated cationic vanadium ions in oxidation states +III +IV, and $+\mathrm{V}$ in solution and solid state, Inorg. Chem. 51 (2012) 9598-9609.

[44] G. Favaro, C. Clementi, A. Romani, V. Vickackaite, Acidichromism and ionochromism of luteolin and apigenin, the main components of the naturally occurring yellow weld: a spectrophotometric and fluorimetric study, J. Fluoresc. 17 (2007) 707-714.

[45] N.D. Chasteen, in: J. Reuben (Ed.), Biological Magnetic Resonance, Plenum, New York, 1981 p. 53 (and references therein).

[46] R. Ando, M. Nagai, T. Yagyu, M. Maeda, Composition and geometry of oxovanadium(IV) and (V)-aminoethanol-Schiff base complexes and stability of their peroxo complexes in solution, Inorg. Chim. Acta 351 (2003) 107-113.

[47] K. Van Norren, E.C. Van Hoorn, H.G.D. Leuvenink, Z. Hofman, Compositions Suitable for the Treatment of Damage Caused by Ischemia/Reper-Fusion or Oxidative Stress, Patent Application Publication, US, 2006 (2006/0270615 A1).

[48] C.L. Si, Y.Y. Lu, Y. Zhang, J. Xu, P.P. Qin, R.C. Sun, Y.H. Ni, Antioxidative low molecular weight extractives from Triploid Populus tomentosa xylem, Bioresources 6 (2011) 232-242.

[49] M. Majewska, M. Skrzycki, M.G. Podsiad, H. Czeczot, Evaluation of antioxidant potential of flavonoids: an in vitro Study, Acta Pol. Pharm. Drug Res. 68 (2011) 611-615.

[50] T. Yi, O. Chen, X. He, S. So, Y. Lo, L. Fan, J. Xu, Y. Tang, J. Zhang, Z. Zhao, H. Chen, Chemical quantification and antioxidant assay of four active components in Ficus hirta root using UPLC-PAD-MS fingerprinting combined with cluster analysis, Chem. Cent. J. 115 (2013) 1-9.

[51] L.G. Naso, L. Lezama, M. Valcarcel, C. Salado, P. Villacé, D. Kortazar, E.G. Ferrer, P. A.M. Williams, Bovine serum albumin binding, antioxidant and anticancer properties of an oxidovanadium(IV) complex with luteolin, J. Inorg. Biochem. 157 (2016) 80-93.

[52] R.H. Patil, R.L. Babu, M.N. Kumar, K.M.K. Kumar, S.M. Hegde, G.T. Ramesh, S.C. Sharma, Apigenin inhibits PMA-induced expression of pro-inflammatory cytokines and AP-1 factors in A549 cells, Mol. Cell Biochem. 403 (2015) 95106.

[53] R. Liu, H. Zhang, M. Yuan, J. Zhou, Q. Tu, J. Liu, J. Wang, Synthesis and biological evaluation of apigenin derivatives as antibacterial and antiproliferative agents, Molecules 18 (2013) 11496-11511.

[54] B. Banik, P.K. Sasmal, S. Roy, R. Majumdar, R.R. Dighe, A.R. Chakravarty, Terpyridine Oxovanadium(IV) complexes of phenanthroline bases for cellular imaging and photocytotoxicity in HeLa cells, Eur. J. Inorg. Chem. 2011 (2011) 1425-1435.

[55] Y. Xu, Y. Xin, Y. Diao, C. Lu, J. Fu, L. Luo, Z. Yin, Synergistic effects of apigenin and paclitaxel on apoptosis of cancer cells, PLoS One 6 (2011) e29169.

[56] E. Szliszka, Z.P. Czuba, K. Jernas, W. Król, Dietary flavonoids sensitize HeLa cells to tumor necrosis factor-related apoptosis-inducing ligand (TRAIL), Int. J. Mol. Sci. 9 (2008) 56-64.

[57] P. Zheng, L. Chiang, C. Lin, Apigenin induced apoptosis through p53-dependent pathway in human cervical carcinoma cells, Life Sci. 76 (2005) 1367-1379.

[58] D. Choudhury, A. Ganguli, D. Ghosh Dastidar, B.R. Acharya, A. Das, G. Chakrabarti, Apigenin shows synergistic anticancer activity with curcumin by binding at different sites of tubulin, Biochimie 5 (2013) 1297-1309.

[59] M. Tan, J. Zhu, Y. Pan, Z. Chen, H. Liang, H. Liu, H. Wang, Synthesis, cytotoxic activity, and DNA binding properties of copper (II) complexes with hesperetin, naringenin, and apigenin, hindawi pub, Corp Bioinorg. Chem. Appl. (2009) 9, doi:http://dx.doi.org/10.1155/2009/347872 (ID 347872).

[60] L.B. Sullivan, N.S. Chande, Mitochondrial reactive oxygen species and cancer, Cancer Metabol. 2 (2014) 1-12.

[61] L. Gibellini, M. Pinti, M. Nasi, S. De Biasi, E. Roat, L. Bertoncelli, A. Cossarizza, Interfering with ROS metabolism in cancer cells: the potential role of quercetin, Cancers 2 (2010) 1288-1311.

[62] B.R. Masella, R. Di Benedetto, R. Varí, C. Filesi, C. Giovannini, Novel mechanisms of natural antioxidant compounds in biological systems: involvement of glutathione and glutathione-related enzymes, J. Nutr. Biochem. 16 (2005) 577586.

[63] O. Zitka, S. Skalickova, J. Gumulec, M. Masarik, V. Adam, J. Hubalek, L. Trnkova, J. Kruseova, T. Eckschlager, R. Kizek, Redox status expressed as GSH:GSSG ratio as a marker for oxidative stress in paediatric tumour patients, Oncol. Lett. 4 (2012) 1247-1253.

[64] R. Kachadouriana, B.J. Day, Flavonoid-induced glutathione depletion: potential implications for cancer treatment, Free Radic. Biol. Med. 41 (2006) 65-76.

[65] S.J. Padayatty, A. Katz, Y. Wang, P. Eck, O. Kwon, J. Lee, S. Chen, C. Corpe, A. Dutta, S.K. Dutta, M. Levine, Vitamin C as an antioxidant: evaluation of its role in disease prevention, J. Am. Coll. Nutr. 22 (2013) 18-35.

[66] N.G. Stephens, A. Parsons, P.M. Schofield, F. Kelly, K. Cheeseman, M.J. Mitchinson, M.J. Brown, Randomised controlled trial of vitamin E in patients with coronary disease, Cambridge Heart Antioxidant Study (CHAOS), vol. 346(1996), pp. 781-786.

[67] A. Lagarto Parra, R. Silva Yhebra, I. Guerra Sardiñas, L. Iglesias Buela, Comparative study of the assay of Artemia salina $L$. and the estimate of the medium lethal dose (LD50 value) in mice, to determine oral acute toxicity of plant extracts, Phytomedicine 8 (2001) 395-400.

[68] Y. Moriyama, D. Ohta, K. Hachiya, Y. Mitsui, K. Takeda, Fluorescence behavior of tryptophan residues of bovine and human serum albumins in ionic surfactant 
solutions: a comparative study of the two and one tryptophan(s) of bovine and human albumins, J. Protein. Chem. 15 (1996) 265-272.

[69] S. Bi, L. Yan, B. Pang, Y. Wang, Investigation of three flavonoids binding to bovine serum albumin using molecular fluorescence technique, J.Lumin 132 (2012) 132-140.

[70] J.R. Lakowicz (Ed.), Principles of Fluorescence Spectroscopy, Springer Science \& Business Media, New York, 2013.

[71] X. Zhao, Y. Liu, L. Niu, C. Zhao, Spectroscopic studies on the interaction of bovine serum albumin with surfactants and apigenin, Spectrochim. Acta A 94 (2012) 357-364.

[72] J. Shi, H. Cao, Molecular structure-affinity relationship of dietary flavonoids for bovine serum albumin, Braz. J. Pharmacogn. 21 (2011) 594-600.
[73] Y. Shang, H. Li, Russ, Studies of the interaction between apigenin and bovine serum albumin by spectroscopic methods, J. Gen. Chem. 80 (2010) 1710-1717.

[74] L. Tang, W. Jia, D. Zhang, The effects of experimental conditions of fluorescence quenching on the binding parameters of apigenin to bovine serum albumin by response surface methods, Luminescence 29 (2014) 344-351.

[75] P.D. Ross, S. Subramanian, Thermodynamics of protein association reactions: forces contributing to stability, Biochemistry 20 (1981) 3096-3102.

[76] T. Topală, A. Bodoki, L. Oprean, R. Oprean, Bovine serum albumin interactions with metal complexes, Clujul Med. 87 (2014) 215-219.

[77] U. Kragh-Hansen, V.T.G. Chuang, M. Otagiri, Practical aspects of the ligandbinding and enzymatic properties of human serum albumin, Biol. Pharm. Bull. 25 (2002) 695-704. 